\title{
34. RADIOLARIA: LEG 6 OF THE DEEP SEA DRILLING PROJECT
}

\author{
Stanley A. Kling, Cities Service Oil Company \\ Exploration/Production Research, Tulsa, Oklahoma
}

\section{CONTENTS}

$\begin{array}{cccc} & \text { Page } & & \text { Page } \\ \text { 1. Introduction } & 1069 & 2.2 .3 \text { Caroline Ridge } & 1083 \\ \text { 2. Cenozoic Radiolaria } & 1069 & \text { Site 55 (Tables 2 \& 3) } & 1084 \\ \text { 2.1 High Latitude Sites } & 1069 & \text { Site 56 (Tables 2 \& 3) } & 1084 \\ \text { 2.1.1 Zonation } & 1069 & \text { Site 57 (Table 3) } & 1084 \\ \text { 2.1.2 Shatsky Rise } & 1070 & \text { Site 58 (Table 3) } & 1085 \\ \text { Site 47 (Table 1) } & 1070 & 2.2 .4 \text { Abyssal Pacific } & 1085 \\ \text { Site 48 (Table 1) } & 1074 & \text { Site 59 (Table 3) } & 1085 \\ \text { Site 49 (Table 1) } & 1074 & 2.2 .5 \text { Discussion } & 1085 \\ \text { Site 50 (Table 1) } & 1074 & \text { 3. Systematics, Cenozoic Radiolaria } & 1086 \\ \text { 2.1.3 Abyssal North Pacific } & 1074 & \text { 4. Mesozoic Radiolaria } & 1089 \\ \text { Site 51 (Table 1) } & 1075 & \text { Site 45 } & 1089 \\ \text { Site 52 } & 1075 & \text { Site 46 } & 1089 \\ \text { 2.1.4 Discussion } & 1075 & \text { Site 49 } & 1090 \\ \text { 2.2 Low Latitude Sites } & 1075 & \text { Site 50 } & 1090 \\ \text { 2.2.1 Zonation } & 1075 & \text { Site .51 } & 1090 \\ \text { 2.2.2 Philippine Basin } & 1083 & \text { Site 52 } & 1090 \\ \text { Site 53 (Table 2) } & 1083 & \text { Site 59 } & 1090 \\ \text { Site 54 (Table 2) } & 1083 & \text { Figures 1 and 2 } & 1090 \\ \text { Site 60 } & 1083 & \text { Plates 1 through 11 } & 1093 \\ & & & 1096\end{array}$

\section{INTRODUCTION}

Radiolaria occur in samples from 15 of the 17 sites drilled during Leg 6 . The combined results of shipboard and shore laboratory studies are reported in this chapter. A total of about 350 slides have been examined, of which approximately 300 contain radiolarians.

The ages of radiolarian-bearing samples range from Cretaceous (possibly upper Jurassic) to Quaternary. Cenozoic faunas are all upper Oligocene or younger and are discussed separately from the Mesozoic faunas. The presentation of results for Cenozoic radiolarians is further subdivided according to zoogeographic provinces into two sections: one dealing with high latitude, the other with low latitude faunas.

Cenozoic species with stratigraphic histories previously documented in some detail (Riedel, 1957, 1959; Riedel and Sanfilippo, in press; Hays, in press) were recorded in all samples studied here. In addition, some species under current investigation by radiolarian specialists (e.g. Sanfilippo and Riedel, in press) are

recorded in as many samples as time permitted. In general, samples near the ends of the ranges of these less well-known species were chosen for re-examination after the initial examination for routine core dating.

Samples are designated in the usual DSDP format accordingly: (hole number, consisting of: site number, decimal point, number of hole in sequence starting with zero)-(core number)-(section number)-(level from top of section in centimeters). Each core is cut into 1.5 -meter sections numbered from the top down. Abbreviations used are as follows: CC - core catcher, $\mathrm{CB}$ - center bit (usually preceded by the two core numbers between which it was retrieved).

\section{CENOZOIC RADIOLARIA}

\subsection{High Latitude Sites}

\subsubsection{Zonation}

Cenozoic radiolarian assemblages from latitudes higher than about $30^{\circ} \mathrm{N}$ usually lack most of the species known to be short-ranging in equatorial sediments. 
This is presumably attributable to a marked influence of ecology on the geographic distribution of Radiolaria. Similar patterns are seen in the distribution of living species. Radiolarians from Leg 6, Sites 47 through 52 are more closely related to those of equivalent age in California than to those of the lower latitude sites (Sites 53 through 60) in the western Pacific.

Hays (in press) has recently proposed a radiolarian zonation for the North Pacific, the general area in which Leg 6, Sites 44 through 52 occur. He defined three Pleistocene and one upper Pliocene zones based on piston core samples. Figure 1 shows the ranges of species and the limits and names of the zones proposed by Hays compared to zonations proposed for sections of similar age in equatorial regions.

Although some of the North Pacific species discussed by Hays (in press) are estimated to range south only to $35^{\circ} \mathrm{N}$, they occur in sufficient numbers in Leg 6 samples (from approximately $32^{\circ} \mathrm{N}$ ) to permit the use of his zones. The tops and bottoms of the ranges of species are in the same sequence as Hays found them.

The Leg 6 samples range stratigraphically lower than those studied by Hays. The oldest samples (Hole 47.2) contain Stichocorys delmontense below the first occurrence of $S$. peregrina, indicating a late Miocene age. The level where $S$. delmontense evolves into $S$. peregrina defines the base of the upper Miocene $S$. peregrina Zone in equatorial regions (Riedel and Sanfilippo, in press). Above this $S$. peregrina Zone is the upper Pliocene Spongaster pentas Zone (on the basis of radiolarian zonation, the Pliocene is informally subdivided into upper and lower units) whose upper limit, defined on the basis of the last appearance of Stichocorys peregrina, is the same as the base of the North Pacific Lamprocyclas heteroporos Zone. Thus, for the high latitude samples, an interval equivalent to the combined $S$. peregrina and Spongaster pentas Zones and including the Miocene-Pliocene boundary cannot at present be subdivided (see Figure 2).

Some possibly useful datum levels below the base of the $L$. heteroporos Zone are noted below, but no new zones are proposed at this time.

Occurrences of Cenozoic Radiolaria in samples from Sites 47, 48, 49, 50, and 51 are shown in Tables 1 through 5. Approximate positions of the zone boundaries are indicated in the column under "ZONE." These tabulations, as well as others in this report, contain only a small proportion of the total number of species present. Abundances are visual estimates indicated as follows: A - abundant, C - common, F - few, R - rare, plus sign - isolated single specimens, minus sign - absence after concentrated search.

\subsubsection{Shatsky Rise}

Sites 47 through 50 are in a relatively shallow area of the western North Pacific covered with Mesozoic to Recent carbonates. Samples from these sites contain Cenozoic Radiolaria in the same age range (late Miocene to Quaternary) and of similar ecology. Although older sediments were cored, no Radiolaria of middle and lower Miocene or Paleogene ages were found. Some Mesozoic assemblages are discussed below.

Site $47\left(32^{\circ} 26.9^{\prime} \mathrm{N}, 157^{\circ} 42.7^{\prime} \mathrm{E}\right.$; depth 2689 meters)

At Site 47, three holes were drilled and cored. Wellpreserved Radiolaria are abundant in chalk oozes of late Miocene to Quaternary age. Below the late Miocene, Radiolaria rapidly disappear.

Samples from Hole 47.0 contain middle to upper Pleistocene Radiolaria. The single core from about 0 to 9 meters below the sea floor contains assemblages of the Stylatractus universus Zone at the bottom. Above these are similar assemblages consistently lacking $S$. universus but containing Druppatractus acquilonius, suggesting that they are in the lowermost part of the Eucyrtidium tumidulum Zone.

A single core, from about 96 to 105 meters below the ocean floor, recovered from Hole 47.1 contains a radiolarian assemblage including Stichocorys peregrika, thus indicating a late Miocene or early Pliocene age.

Hole 47.2 contains a continuous sequence of Radiolaria from the middle Pleistocene (about 9 meters below the ocean floor) through the upper Miocene (about 67 meters below the ocean floor). Core 1 contains an assemblage of the middle Pleistocene Stylatractus universus Zone. Below this the Eucyrtidium matuyamai and Lamprocyclas heteroporos Zones are represented. Samples below the $L$. heteroporos Zone contain common to abundant Stichocorys peregrina through the top of Core 7, indicating ages equivalent to the lower Pliocene Spongaster pentas and upper Miocene Stichocorys peregrina equatorial zones. Radiolaria become rare in Core 7; Section 2, the last in Hole 47.2 to bear radiolarians, contains $S$. delmontense, suggesting a correlation below the base of the $S$. peregrina Zone.

Five cores below Core 7 in Hole 47.2, to a total depth of about 424 meters below the ocean floor, contained no Radiolaria.

Site $48\left(32^{\circ} 24.5^{\prime} \mathrm{N}, 158^{\circ} 01.3^{\prime} \mathrm{E}\right.$; depth 2619 meters $)$

Three holes were drilled at this site. Radiolaria of variable abundance and preservation occur in chalk oozes from the upper Miocene to lower Pliocene.

A sample of fluid outwash was obtained from about 84 meters below the ocean floor in Hole 48.0. No Radiolaria were found in the small amount of available sample. 
TABLE 1

\begin{tabular}{|c|c|c|c|c|c|c|c|c|c|}
\hline Sample & 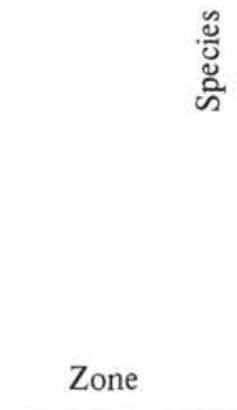 & 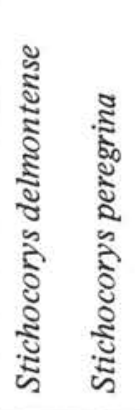 & 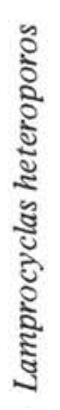 & 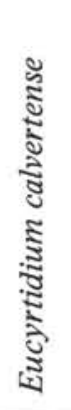 & 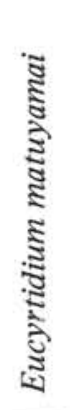 & 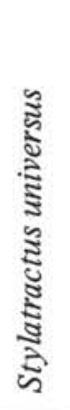 & 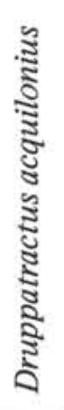 & 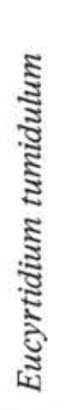 & 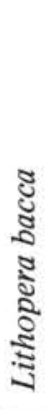 \\
\hline Hole 47.0 & \multirow{8}{*}{$\begin{array}{l}\text { Eucyrtidium } \\
\text { tumidulum }\end{array}$} & & & & & & & & \\
\hline 47.0-1-Top & & & - & $\mathrm{F}$ & & & $\mathrm{F}$ & $\mathrm{F}$ & $\mathrm{F}$ \\
\hline $47.0-1-1,83-85$ & & & - & $\mathrm{F}$ & & - & $\mathrm{F}$ & - & - \\
\hline $47.0-1-2,66-68$ & & & - & $\mathrm{R}$ & & - & $\mathrm{F}$ & $\mathrm{F}$ & - \\
\hline $47.0-1-3,72-74$ & & & & $\mathrm{R}$ & & & $\mathrm{F}$ & $\mathrm{F}$ & $\mathrm{R}$ \\
\hline $47.0-1-4,49-51$ & & & & $\mathrm{R}$ & & - & $\mathrm{F}$ & $\mathrm{F}$ & \\
\hline $47.0-1-4,74-76$ & & & & $\mathrm{R}$ & & - & $\mathrm{F}$ & $\mathrm{R}$ & $\mathrm{R}$ \\
\hline $47.0-1-5,6-8$ & & & & $\mathrm{R}$ & & - & $\mathrm{F}$ & $\mathrm{R}$ & $\mathrm{R}$ \\
\hline $47.0-1-5,78-80$ & \multirow{3}{*}{$\begin{array}{l}\text { Stylatractus } \\
\text { universus }\end{array}$} & & & $\mathrm{R}$ & & $\mathrm{F}$ & $\mathrm{F}$ & $\mathrm{F}$ & \\
\hline $47.0-1-6,75-77$ & & & & $\mathrm{R}$ & & $\mathrm{F}$ & $\mathrm{F}$ & $\mathrm{F}$ & \\
\hline $47.0-1-\mathrm{CC}$ & & & & $\mathrm{R}$ & & $\mathrm{R}$ & $\mathrm{F}$ & $\mathrm{F}$ & $\mathrm{R}$ \\
\hline \multicolumn{10}{|l|}{ Hole 47.1} \\
\hline 47.1-1-Тop & \multirow{3}{*}{$?$} & C & & $F$ & & & $\mathrm{~F}$ & & $\mathrm{~F}$ \\
\hline $47.1-1-1,145-150$ & & $\mathrm{C}$ & & $\mathrm{R}$ & & & $\mathrm{C}$ & & \\
\hline $47.1-1-\mathrm{CC}$ & & $\mathrm{C}$ & & $\mathrm{R}$ & & & $\mathrm{C}$ & & \\
\hline \multicolumn{10}{|l|}{ Hole 47.2} \\
\hline $47.2-1-1,140-145$ & \multirow{5}{*}{$\begin{array}{l}\text { Stylatractus } \\
\text { universus }\end{array}$} & & & $\mathrm{R}$ & & $\mathrm{R}$ & C & $\mathrm{R}$ & \\
\hline $47.2 \cdot 1-2,10-11$ & & & & $\mathrm{~F}$ & & $\mathrm{~F}$ & $\mathrm{~F}$ & $\mathrm{~F}$ & \\
\hline $47.2 \cdot 1-3,21-23$ & & & & $\mathrm{~F}$ & & & $\mathrm{~F}$ & $\mathrm{~F}$ & \\
\hline $47.2-1 \cdot 4,16-18$ & & & & $\mathrm{~F}$ & & $\mathrm{R}$ & $\mathrm{F}$ & $\mathrm{F}$ & \\
\hline $47.2-2-2,18-20$ & & & & $\mathrm{~F}$ & & $\mathrm{R}$ & $\mathrm{F}$ & $\mathrm{F}$ & $\mathrm{R}$ \\
\hline $47.2-2-2,80-82$ & \multirow{3}{*}{$\begin{array}{l}\text { Eucyrtidium } \\
\text { matuyamai }\end{array}$} & & & $\mathrm{R}$ & $\mathrm{R}$ & $\mathrm{F}$ & $\mathrm{F}$ & $\mathrm{F}$ & \\
\hline $47.2-2-3,18-20$ & & & & $\mathrm{~F}$ & $\mathrm{R}$ & $\mathrm{F}$ & $\mathrm{F}$ & $\mathrm{F}$ & \\
\hline $47.2-2-4,18-20$ & & & & $\mathrm{~F}$ & $\mathrm{R}$ & $\mathrm{F}$ & $\mathrm{F}$ & $\mathrm{R}$ & \\
\hline
\end{tabular}


TABLE 1 - Continued

\begin{tabular}{|c|c|c|c|c|c|c|c|c|c|c|}
\hline Sample & 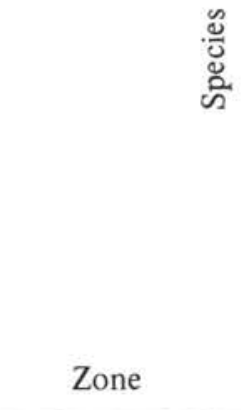 & 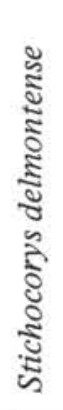 & 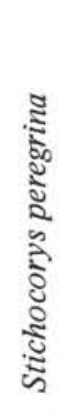 & 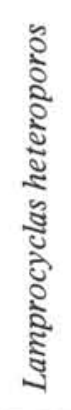 & 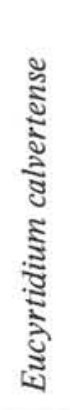 & 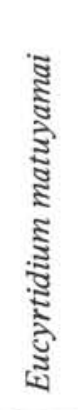 & 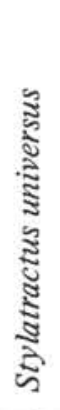 & 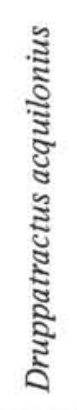 & 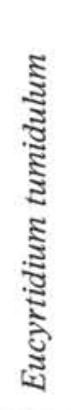 & 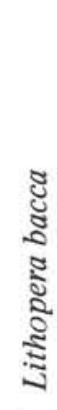 \\
\hline Hole 47.2 - Continued & $\begin{array}{l}\text { Eucyrtidium } \\
\text { matuyamai }\end{array}$ & & & & & & & & & \\
\hline $47.2-2-4,78-80$ & & & & & $\mathrm{R}$ & $\mathrm{R}$ & $\mathrm{F}$ & $\mathrm{F}$ & $\mathrm{R}$ & \\
\hline $47.2-2-5,16-18$ & & & & $\mathrm{~F}$ & $\mathrm{~F}$ & & $\mathrm{R}$ & F & $\mathrm{F}$ & $\mathrm{F}$ \\
\hline $47.2-2-5,78-80$ & & & & $\mathrm{R}$ & $\mathrm{F}$ & & $\mathrm{F}$ & $\mathrm{F}$ & & \\
\hline $47.2-2-6,18-20$ & & & & + & $\mathrm{F}$ & & & $\mathrm{F}$ & $\mathrm{F}$ & \\
\hline $47.2-2-6,71-73$ & & & & $\mathrm{R}$ & $\mathrm{F}$ & & $\mathrm{F}$ & $\mathrm{F}$ & $\mathrm{F}$ & \\
\hline $47.2-2-\mathrm{CC}$ & Lamprocyclas & & & + & $\mathrm{F}$ & & & $\mathrm{F}$ & $\mathrm{F}$ & \\
\hline $47.2-3-1,130-132$ & & & & & $\mathrm{~F}$ & & $\mathrm{R}$ & $\mathrm{C}$ & $\mathrm{F}$ & \\
\hline $47.2-3-2,15-17$ & & & & $\mathrm{R}$ & $\mathrm{C}$ & & $?$ & $\mathrm{~F}$ & & \\
\hline $47.2-3-3,16-18$ & & & & & $\mathrm{~F}$ & & $\mathrm{~F}$ & F & $\mathrm{F}$ & \\
\hline $47.2-3-4,7-9$ & & & & $\mathrm{R}$ & $\mathrm{F}$ & & & F & & \\
\hline $47.2-3-\mathrm{CC}$ & & & $\mathrm{C}$ & $\mathrm{R}$ & $\mathrm{F}$ & & & $\mathrm{F}$ & $\mathrm{F}$ & $\mathrm{R}$ \\
\hline $47.2-4-1,20-22$ & & & $\mathrm{R}$ & $\mathrm{R}$ & $\mathrm{F}$ & & + & $\mathrm{F}$ & & \\
\hline $47.2-4-2,19-21$ & & & + & $\mathrm{R}$ & $\mathrm{F}$ & & & F & $\mathrm{F}$ & $\mathrm{F}$ \\
\hline $47.2-4-3,6-8$ & & & $\mathrm{C}$ & $\mathrm{R}$ & $\mathrm{F}$ & & $\mathrm{R}$ & $\mathrm{F}$ & - & - \\
\hline $47.2-4-4,6-8$ & & & $\mathrm{C}$ & + & $\mathrm{F}$ & & $\mathrm{R}$ & $\mathrm{R}$ & - & $\mathrm{F}$ \\
\hline $47.2-4-5,25-27$ & & & $\mathrm{C}$ & & $\mathrm{F}$ & & - & $\mathrm{F}$ & - & $\mathrm{R}$ \\
\hline $47.2-4 \cdot 6,6-8$ & & & $\mathrm{C}$ & - & $\mathrm{F}$ & & - & F & - & $\mathrm{F}$ \\
\hline 47.2-4-CC & & & $\mathrm{C}$ & & $\mathrm{R}$ & & & F & & $\mathrm{F}$ \\
\hline $47.2-5-2,18-20$ & & & $\mathrm{C}$ & + & $\mathrm{F}$ & & & F & $\mathrm{F}$ & \\
\hline $47.2 \cdot 5-3,16-18$ & & & $\mathrm{C}$ & & $\mathrm{F}$ & & & F & & $\mathrm{F}$ \\
\hline $47.2-5-4,17 \cdot 19$ & $?$ & & $\mathrm{C}$ & & $\mathrm{F}$ & & & $\mathrm{R}$ & & $\mathrm{F}$ \\
\hline $47.2 \cdot 5 \cdot 6,15 \cdot 17$ & & & $\mathrm{C}$ & & $\mathrm{R}$ & & & $\mathrm{R}$ & & $\mathrm{F}$ \\
\hline $47.2-6-2,26-28$ & & & A & + & $\mathrm{F}$ & & $\mathrm{R}$ & $\mathrm{F}$ & & \\
\hline $47.2-6-3,24-26$ & & & $\mathrm{C}$ & & $\mathrm{F}$ & & & $\mathrm{F}$ & & $\mathrm{R}$ \\
\hline 47.2-6-Bottom & & & $\mathrm{C}$ & & $\mathrm{R}$ & & & $\mathrm{R}$ & & $\mathrm{R}$ \\
\hline $47.2-7-1,5-7$ & & & $\mathrm{~F}$ & & & & & $\mathrm{~F}$ & & $\mathrm{R}$ \\
\hline $47.2-7-2,27-29$ & & $\mathrm{C}$ & & & & & & & & $\mathrm{F}$ \\
\hline
\end{tabular}


TABLE 1 - Continued

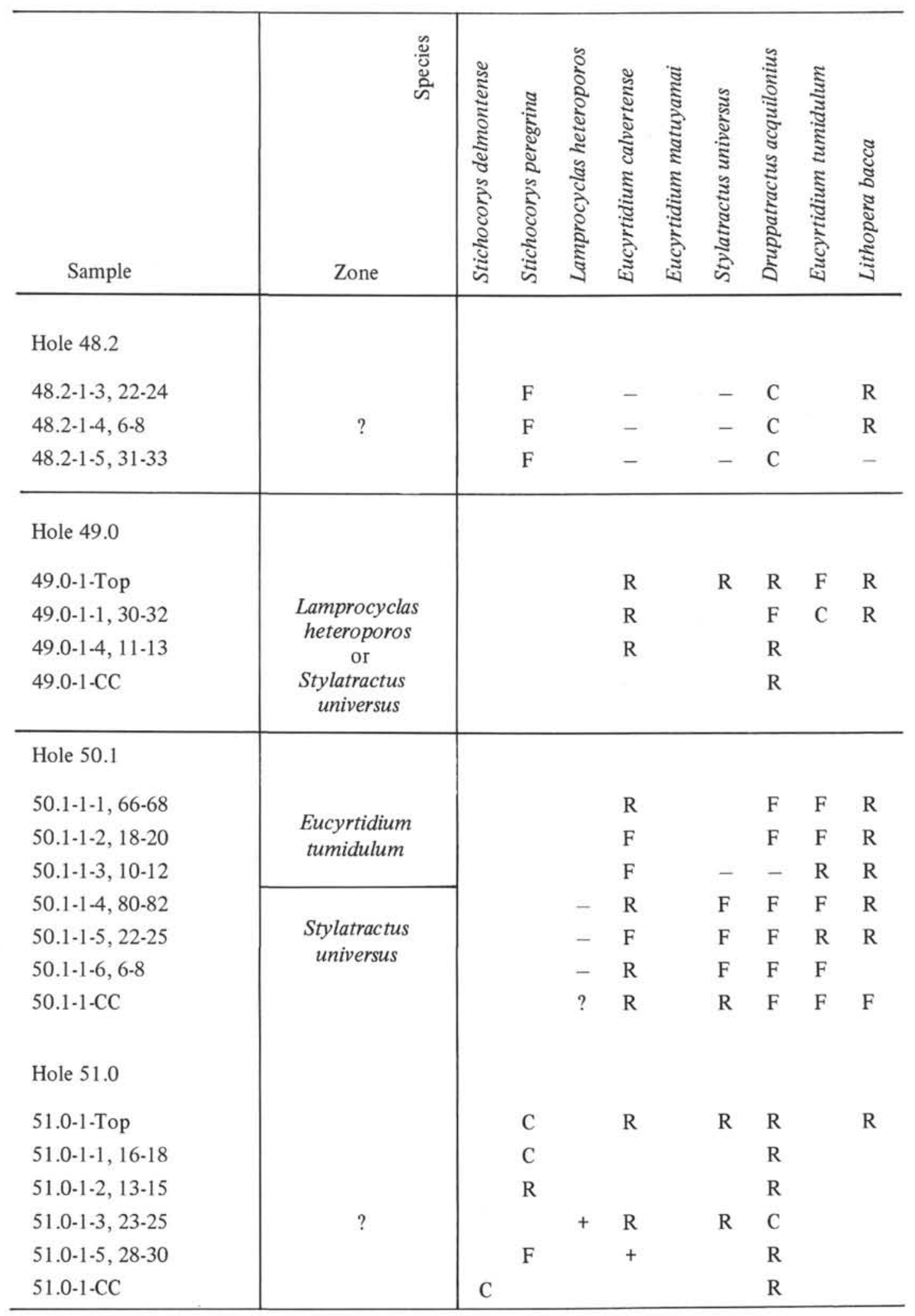


TABLE 1 - Continued

\begin{tabular}{|c|c|c|c|c|c|c|c|c|c|c|}
\hline Sample & $\begin{array}{l}\tilde{\partial} \\
\text { జू } \\
\text { के }\end{array}$ & 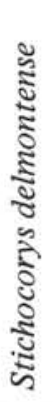 & 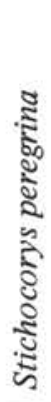 & 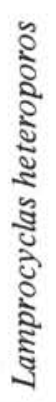 & 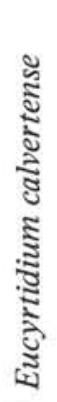 & 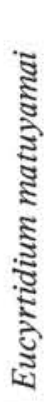 & 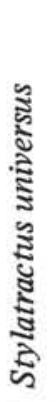 & 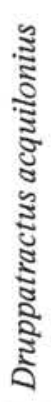 & 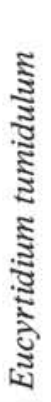 & 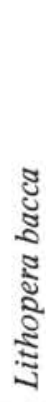 \\
\hline Hole 51.1 & & & & & & & & & & \\
\hline 51.1-1-Top & \multirow{4}{*}{$\begin{array}{l}\text { Eucyrtidium } \\
\text { matuyamai }\end{array}$} & & & & $\mathrm{R}$ & + & F & $\mathrm{R}$ & $\mathrm{F}$ & \\
\hline $51.1-1-1,2-4$ & & & & & $\mathrm{R}$ & $\mathrm{F}$ & & $\mathrm{F}$ & $\mathrm{F}$ & \\
\hline $51.1-1-3,3-5$ & & & & & F & $\mathrm{R}$ & & $\mathrm{F}$ & $\mathrm{F}$ & \\
\hline $51.1-1-5,2-4$ & & & & & $\mathrm{~F}$ & $\mathrm{R}$ & & $\mathrm{F}$ & $\mathrm{F}$ & \\
\hline $51.1-1-6,3-5$ & \multirow{2}{*}{$\begin{array}{c}\text { Lamprocyclas } \\
\text { heteroporos }\end{array}$} & & & + & $\mathrm{F}$ & - & & $\mathrm{F}$ & $\mathrm{F}$ & $\mathrm{R}$ \\
\hline $51.1-1-\mathrm{CC}$ & & & & $\mathrm{R}$ & $\mathrm{F}$ & - & $\mathrm{F}$ & $\mathrm{R}$ & $\mathrm{F}$ & \\
\hline
\end{tabular}

A single core from about 48 to 49 meters below the ocean floor in Hole 48.1 contains sparse and broken radiolarians. Relatively abundant specimens of Stichocorys peregrina and Druppatractus acquilonius among the identifiable species suggest a late Miocene or early Pliocene age.

Core 1 of Hole 48.2 (about 51 to 60 meters below the ocean floor) contains abundant, well-preserved Radiolaria in the upper part. Abundance decreases and preservation is poorer toward the bottom. All assemblages contain Stichocorys peregrina, which ranges through the upper Miocene $S$. peregrina and lower Pliocene Spongaster pentas Zones in equatorial regions. Lower cores in Holes 48.2 to subbottom depths of 72 meters contain Cretaceous calcareous microfossils, but no radiolarians.

Site $49\left(32^{\circ} 24.1^{\prime} \mathrm{N}, 156^{\circ} 35.0^{\prime} \mathrm{E}\right.$; depth 4282 meters) One of the two holes drilled at this site produced samples of brown clay bearing Cenozoic Radiolaria. Mesozoic assemblages from both holes are discussed below.

A shallow core from Hole 49.0 (about 0 to 10 meters below the ocean floor) contains fairly abundant, wellpreserved Cenozoic radiolarians at the top with sporadic occurrences below. Assemblages at the top indicate, at face value, the middle Pleistocene Stylatractus universus Zone. But the same assemblage with Lamprocyclas heteroporos would indicate the upper Pliocene zone named for that species. In view of the generally rare and infrequent occurrences of $L$. heteroporos in this region, it is not possible to say with great confidence which of the two zones is represented.

Site $50\left(32^{\circ} 24.2^{\prime} \mathrm{N}, 156^{\circ} 36.0^{\prime} \mathrm{E}\right.$; depth 4487 meters $)$ The second of two holes at this site produced abundant, well-preserved Cenozoic radiolarians in siliceous and calcareous clays. Both holes contained the Mesozoic assemblages discussed below.

Core 1 of Hole 50.1 , from about 5 to 15 meters below the sea floor, contains radiolarian assemblages in the upper half that contain Druppatractus acquilonius but consistently lack Stylatractus universus, suggesting that they belong to the lower part of the upper Pleistocene Eucyrtidium tumidulum Zone. In the lower half, $S$. universus consistently appears indicating the middle Pleistocene zone named for that species.

\subsubsection{Abyssal North Pacific}

Sites 51 and 52 are on the abyssal floor of the western North Pacific. Cenozoic radiolarian assemblages from 
these sites are similar to those of corresponding ages from the Shatsky Rise and elsewhere in the Pacific north of about $30^{\circ} \mathrm{N}$. Like the Shatsky Rise sites, no Cenozoic radiolarians older than upper Miocene were found at these sites. Poorly preserved Mesozoic radiolarians were found in the deeper parts of the holes.

Site $51\left(33^{\circ} 28.5^{\prime} \mathrm{N}, 153^{\circ} 24.3^{\prime} \mathrm{E}\right.$; depth 5981 meters)

Both of the two holes drilled at this site contain Cenozoic radiolarians in dark brown clays overlying hard sediments bearing Mesozoic radiolarians.

The single core of soft sediment from Hole 51.0, about 114 to 123 meters below the sea floor, contains radiolarian assemblages of variable abundance. Stichocorys peregrina is consistently present in samples above the core catcher. This indicates an equivalence with the combined ranges of the equatorial Spongaster pentas (lower Pliocene) and Stichocorys peregrina (upper Miocene) Zones. The core catcher contains Stichocorys delmontense but lacks $S$. peregrina, suggesting that the lower part of the core at least is upper Miocene rather than lower Pliocene.

Core 1 of Hole 51.1, about 23 to 32 meters below the ocean floor, contains a sequence of Pliocene-Pleistocene Radiolaria. The upper and middle parts of the core contain Eucyrtidium matuyamai and other species of the lower Pleistocene zone named for that species. The lower part of the core is in the upper Pliocene Lamprocyclas heteroporos Zone.

\section{Site $52\left(27^{\circ} 47.3^{\prime} \mathrm{N}, 147^{\circ} 07.8^{\prime} \mathrm{E}\right.$; depth 5744 meters $)$}

The first three cores of the single hole drilled at this site, from the sea floor to a depth of about 24 meters, contain rare, sporadically occurring Cenozoic radiolarians in brown ashy clays. The stratigraphically significant species, E. calvertense and Druppatractus acquilonius, range from upper Miocene through middle Pleistocene.

Cores 4, 5 and 6 contain no Radiolaria while Cores 7 through 10 to a subbottom depth of about 69 meters contain poorly preserved Mesozoic assemblages. Core 10 also contains Cenozoic species, probably as drilling contamination.

\subsubsection{Discussion}

The long, continuous sequence provided by Hole 47.2 provides data which is sufficient to indicate the first appearances of several species that may be useful, with additional confirmation, for a further subdivision of the radiolarian zonation for the North Pacific region.

The first appearance of Eucyrtidium tumidulum occurs in Section 2 of Core 4 from Hole 47.2 (Table 1). This is about 4 meters below the base of the Lamprocyclas heteroporos Zone. E. tumidulum also co-occurs with Stichocorys peregrina in this lower part of its range. It does not occur in other cores containing $S$. peregrina (e.g. 47.1-1, 48.2-1, 51.0-1, Table 1). This suggests that the first appearance of E. tumidulum occurs somewhere in the lower Pliocene. An isolated occurrence of this species in 47.2-5, Section 2, where $L$. heteroporos also reappears is considered to be caused by drilling contamination.

The first appearance of Stylatractus universus occurs about 3 meters below the first appearance of E. tumidulum. S. universus co-occurs with Stichocorys peregrina in isolated samples (51.0-1, Table 1) other than those of 47.2. Assuming that the range of $S$. peregrina is approximately evenly distributed above and below the Miocene-Pliocene boundary and that sedimentation rates were uniform, the considerable thickness of $S$. peregrina-bearing sediment below the base of Stylatractus universus suggests that this level occurs within the lower Pliocene. An isolated occurrence of this species in 47.2-6 (Table 1) is also considered attributable to drilling contamination.

The first appearances of Druppatractus acquilonius and E. calvertense occur within 1 or 2 meters of one another and about 1 or 2 meters above the first appearance of Stichocorys peregrina in 47.2. Both E. calvertense and $D$. acquilonius co-occur with $S$. peregrina in 47.1-1 and $51.0-1$, where $D$. acquilonius overlaps with $S$. delmontense below the base of $S$. peregrina in one sample. In $48.2, D$. acquilonius co-occurs with $S$. peregrina where $E$. calvertense is lacking. The evidence suggests that the first appearance of Eucyrtidium calvertense may occur slightly above that of Druppatractus acquilonius and that both levels occur near the level at which Stichocorys delmontense evolves into $S$. peregrina.

\subsection{Low Latitude Sites}

\subsubsection{Zonation}

Cenozoic radiolarian assemblages were obtained during Leg 6 from the Philippine Sea and Caroline Ridge areas. South of $30^{\circ} \mathrm{N}$, these are similar in species composition to those commonly encountered in equatorial regions. Riedel and Sanfilippo (in press) have proposed a radiolarian zonation for Leg 4 Radiolaria from the Atlantic Ocean including information from many other equatorial samples, both from ocean sediments and outcrops on land. This zonation is applicable to Leg 6 


\begin{tabular}{|c|c|c|c|c|c|c|c|c|c|c|c|c|c|c|c|c|c|c|c|c|c|c|c|}
\hline SAMPLE & ZONE & 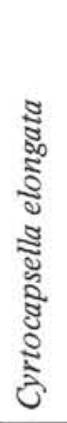 & 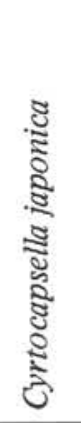 & 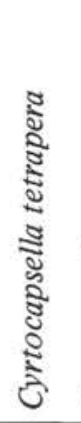 & 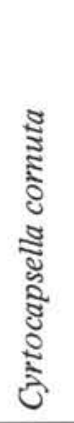 & 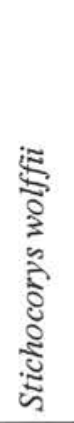 & 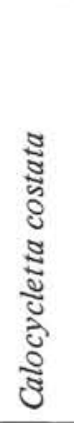 & 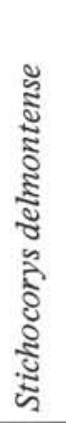 & 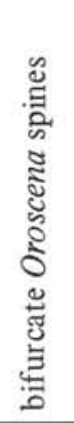 & 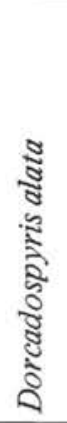 & 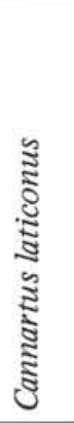 & 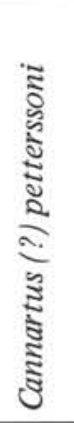 & 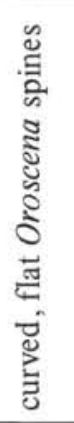 & 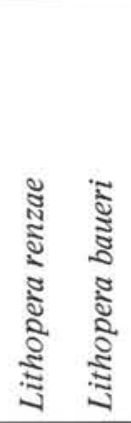 & 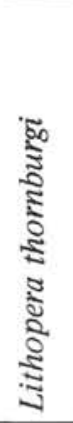 & 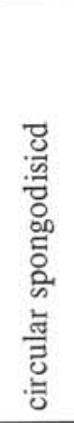 & 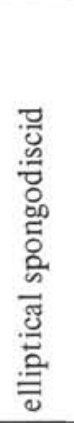 & 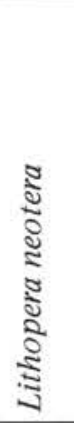 & 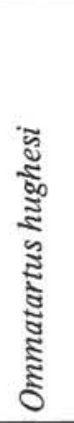 & 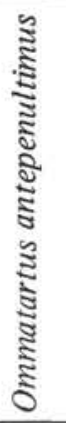 & 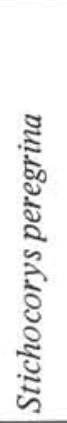 & 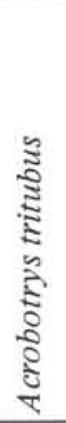 & 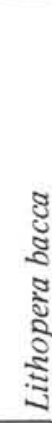 \\
\hline $\begin{array}{l}\text { Hole } 53.0 \\
53.0-2 / 3-\mathrm{CB}\end{array}$ & \multirow{9}{*}{$\begin{array}{c}\text { Ommatartus } \\
\text { antepenultimus }\end{array}$} & \multirow{12}{*}{+} & & & & $\mathrm{R}$ & & & & & & & & & & & & & $\mathrm{F}$ & $\mathrm{C}$ & & & \\
\hline $\begin{array}{l}53.1 \\
53.1-2-\text { Top }\end{array}$ & & & & & & $\mathrm{F}$ & & & & & & & & & & & $\mathrm{R}$ & & $\mathrm{F}$ & $\mathrm{C}$ & $\mathrm{F}$ & + & $\mathrm{R}$ \\
\hline $53.1-2-1,145-150$ & & & & & & $\mathrm{C}$ & & & & & & & & & & $\mathrm{R}$ & - & $\mathrm{R}$ & $\mathrm{C}$ & $\mathrm{C}$ & $\mathrm{F}$ & & $\mathrm{F}$ \\
\hline $53.1-2-2,145-150$ & & & & & & $\mathrm{C}$ & & & & & & $\mathrm{R}$ & & & & $\mathrm{R}$ & - & $\mathrm{R}$ & $\mathrm{C}$ & $\mathrm{C}$ & $\mathrm{F}$ & & $\mathrm{F}$ \\
\hline $53.1-2-3,103-105$ & & & & & & F & $\mathrm{R}$ & & & & & & & & & $\mathrm{R}$ & & $\mathrm{R}$ & $\mathrm{F}$ & $\mathrm{C}$ & $\mathrm{C}$ & & $\mathrm{F}$ \\
\hline $53.1-2-4,20-22$ & & & & & & $\mathrm{C}$ & $\mathrm{R}$ & & & & & & + & & & & & - & $\mathrm{R}$ & $\mathrm{C}$ & $\mathrm{C}$ & & $\mathrm{F}$ \\
\hline $53.1-2-6,11-13$ & & & & & & $\mathrm{R}$ & $\mathrm{R}$ & & & & & & & & & $\mathrm{F}$ & & $\mathrm{R}$ & $\mathrm{F}$ & $\mathrm{C}$ & $\mathrm{C}$ & & $\mathrm{F}$ \\
\hline $53.1-2-\mathrm{CC}$ & & & & & & F & $\mathrm{R}$ & & & & & & & & & $\mathrm{R}$ & & & $\mathrm{R}$ & $\mathrm{C}$ & $\mathrm{C}$ & & \\
\hline $53.1-3-1,150$ & & & & & & & & $\mathrm{R}$ & + & & & & $\mathrm{R}$ & & & & & + & & $\mathrm{F}$ & & & \\
\hline $53.1-3-2,22-24$ & \multirow{3}{*}{$\begin{array}{c}\text { Cannartus (?) } \\
\text { petterssoni }\end{array}$} & & & & $\mathrm{F}$ & & & $\mathrm{R}$ & $\mathrm{R}$ & & $\mathrm{C}$ & & $\mathrm{R}$ & & $\mathrm{R}$ & $\mathrm{R}$ & & $\mathrm{F}$ & & & & & $\mathrm{R}$ \\
\hline $53.1-3-3,3-5$ & & & + & & + & & & $\mathrm{C}$ & $\mathrm{R}$ & & A & & $\mathrm{R}$ & & & $\mathrm{R}$ & & $\mathrm{F}$ & & & & & $\mathrm{R}$ \\
\hline $53.1-3-\mathrm{CC}$ & & & & & & & & $\mathrm{R}$ & $\mathrm{C}$ & & & & $\mathrm{C}$ & & & & & $\mathrm{F}$ & & & & & \\
\hline \multicolumn{24}{|l|}{ Hole 53.2} \\
\hline $53.2-1-2,23-25$ & \multirow{6}{*}{$\begin{array}{c}\text { Ommatartus } \\
\text { antepenultimus }\end{array}$} & & & & & & & - & & & & & & & & $\mathrm{R}$ & $\mathrm{R}$ & $\mathrm{R}$ & $\mathrm{C}$ & $\mathrm{C}$ & A & $\mathrm{R}$ & $\mathrm{F}$ \\
\hline $53.2-1-3,13-15$ & & & & & & & & - & & & & & & & & $\mathrm{R}$ & $\mathrm{R}$ & $\mathrm{F}$ & $\mathrm{C}$ & $\mathrm{C}$ & A & - & $\mathrm{R}$ \\
\hline $53.2-1-4,15-17$ & & & & & & & & - & & & & & & & & $\mathrm{R}$ & $\mathrm{R}$ & $\mathrm{F}$ & $\mathrm{C}$ & $\mathrm{C}$ & $\mathrm{C}$ & - & $\mathrm{R}$ \\
\hline $53.2-1-5,11-13$ & & & & & & & & - & & & & & & & & $\mathrm{R}$ & $\mathrm{R}$ & $\mathrm{F}$ & $\mathrm{C}$ & $\mathrm{C}$ & $\mathrm{C}$ & - & $\mathrm{F}$ \\
\hline $53.2-1-6,13-15$ & & & & & & & & - & & & & & & & & & & $\mathrm{F}$ & $\mathrm{C}$ & $\mathrm{F}$ & $\mathrm{C}$ & - & $\mathrm{F}$ \\
\hline 53.2-1-Bottom & & & & & & & & $\mathrm{F}$ & & & & $\mathrm{R}$ & & & & $\mathrm{F}$ & - & $\mathrm{F}$ & $\mathrm{C}$ & $\mathrm{C}$ & $\mathrm{C}$ & & F \\
\hline
\end{tabular}


TABLE 2 - Continued

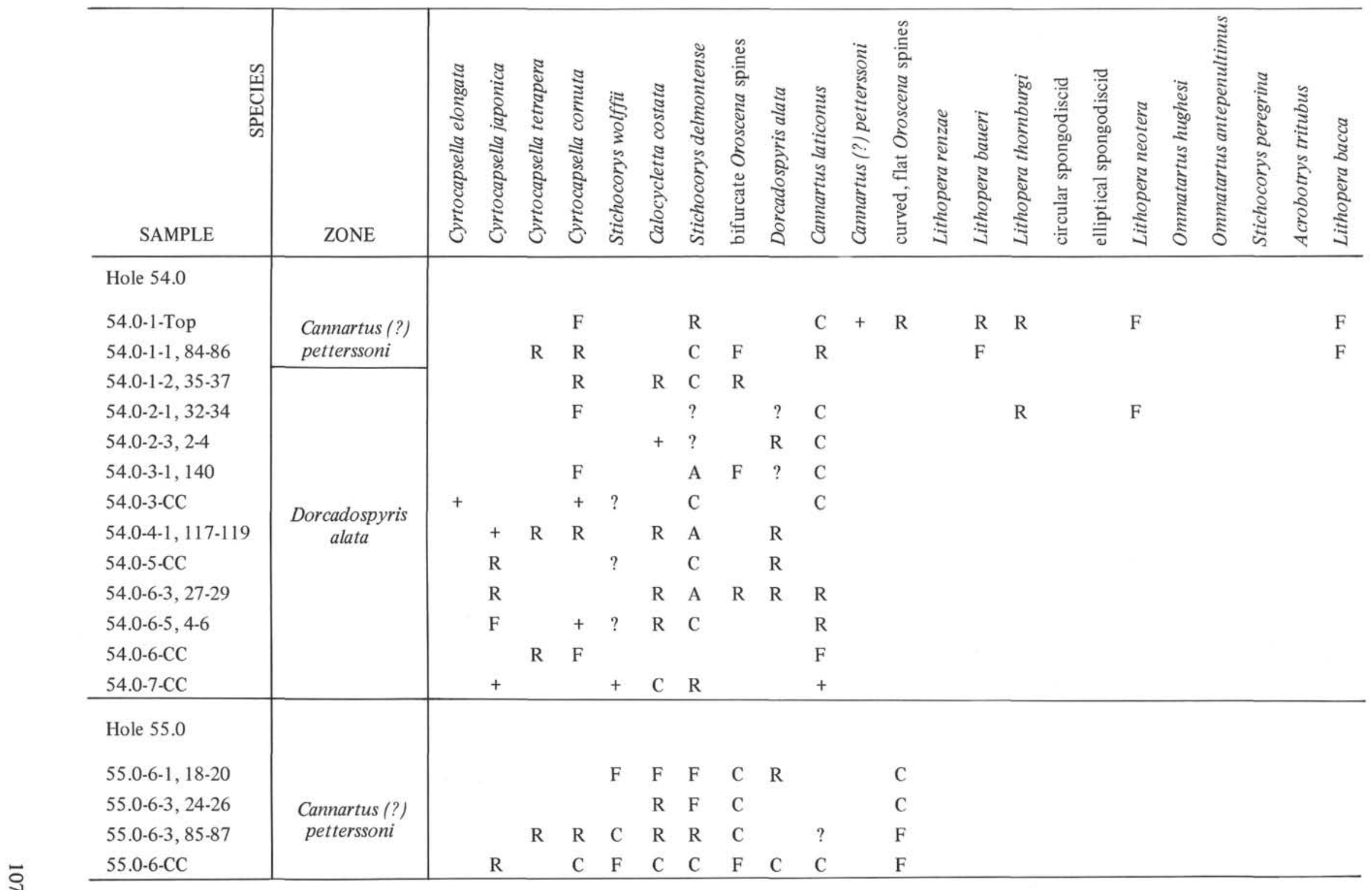


$\underset{\infty}{\circ}$

TABLE 2 - Continued

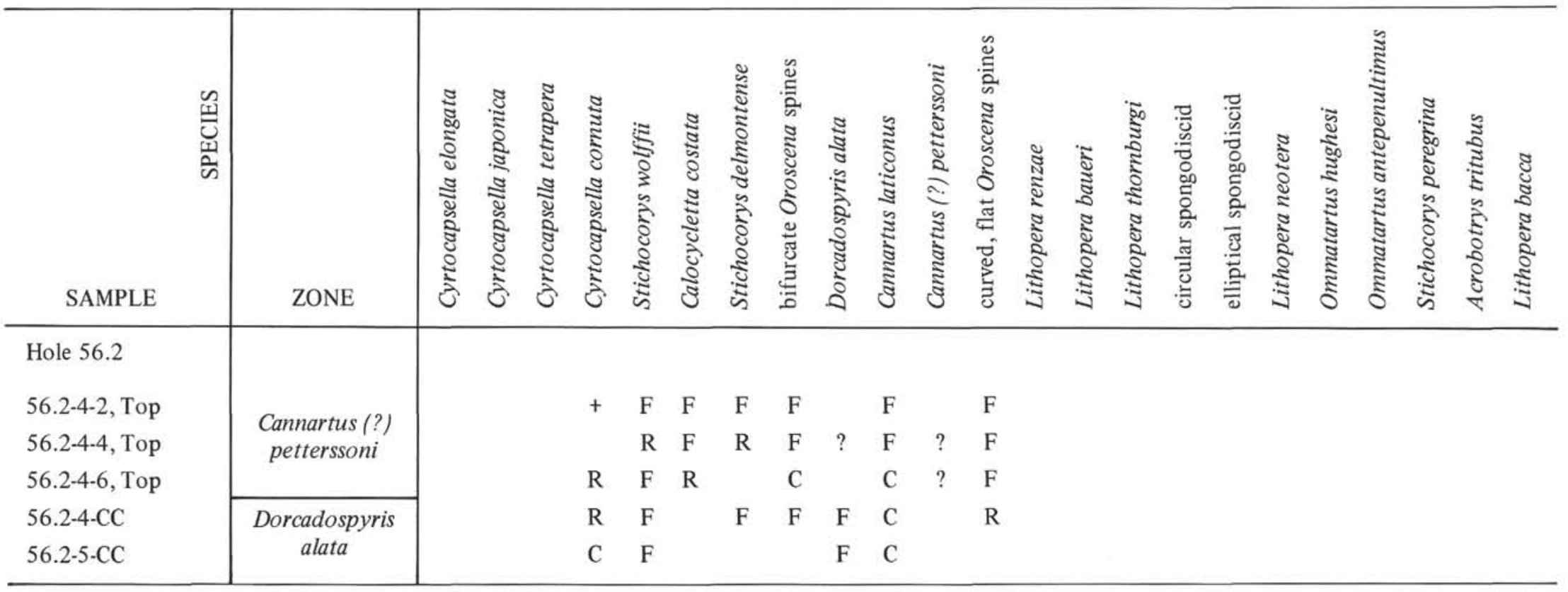


TABLE 3

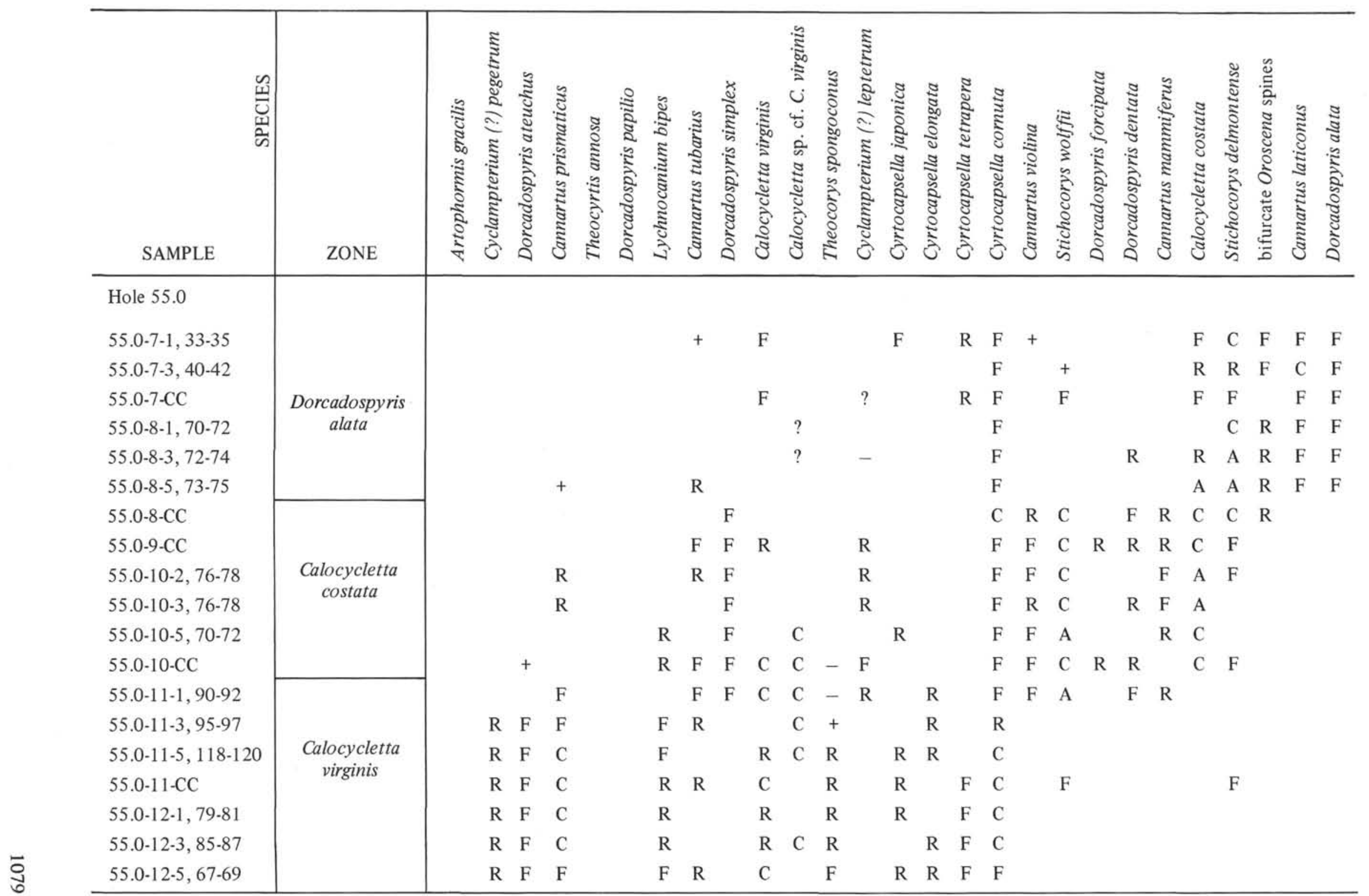




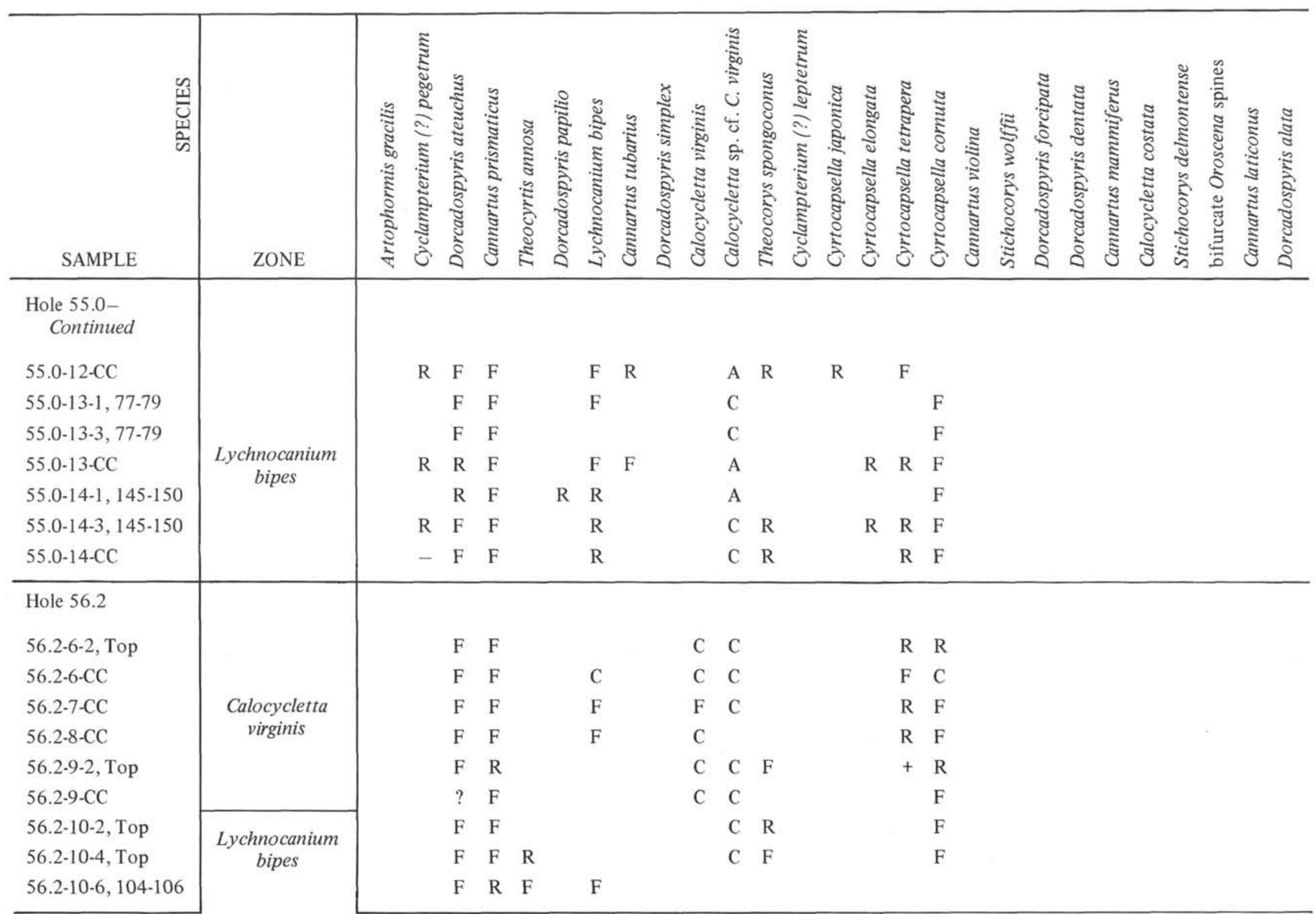




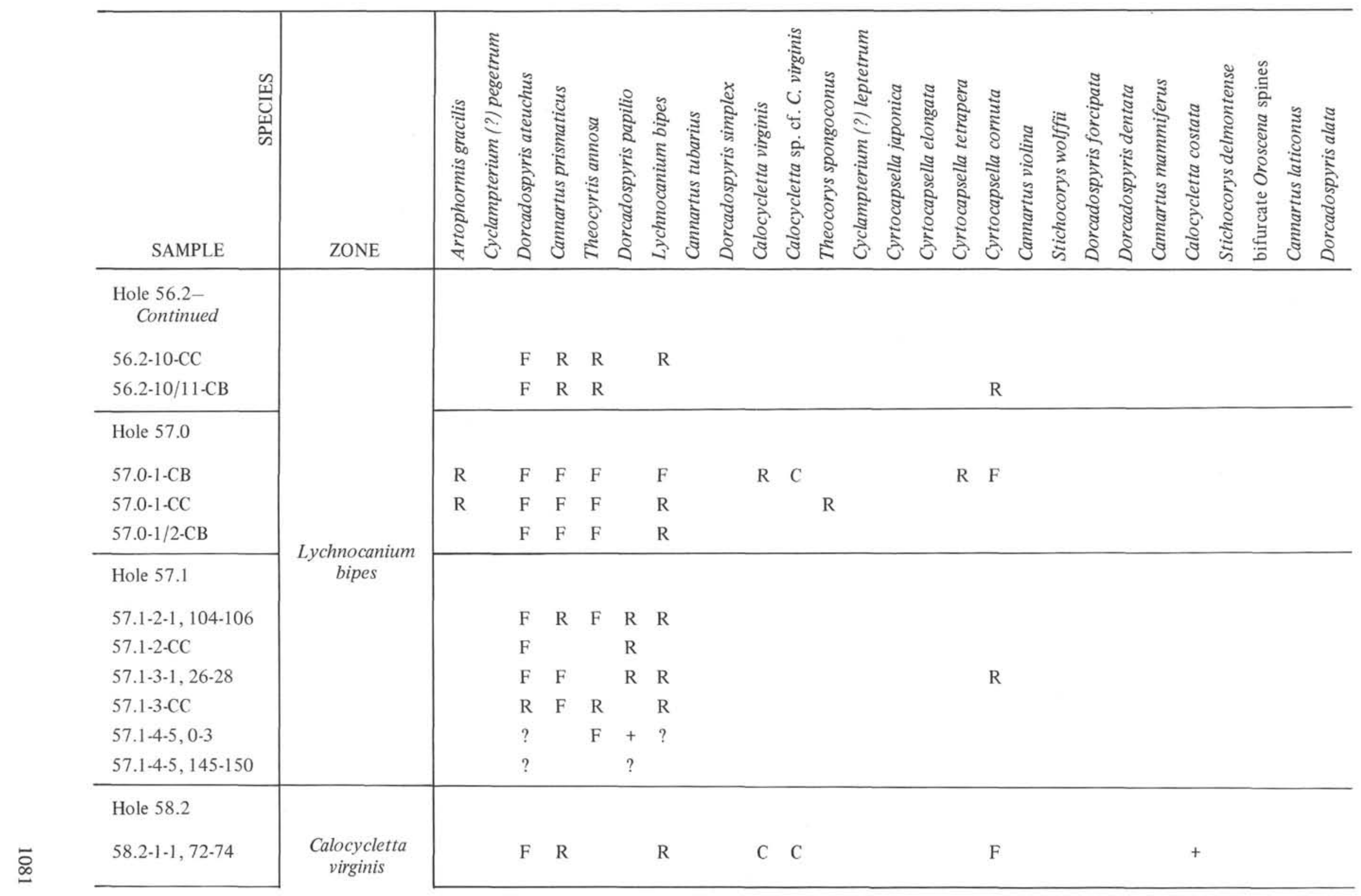




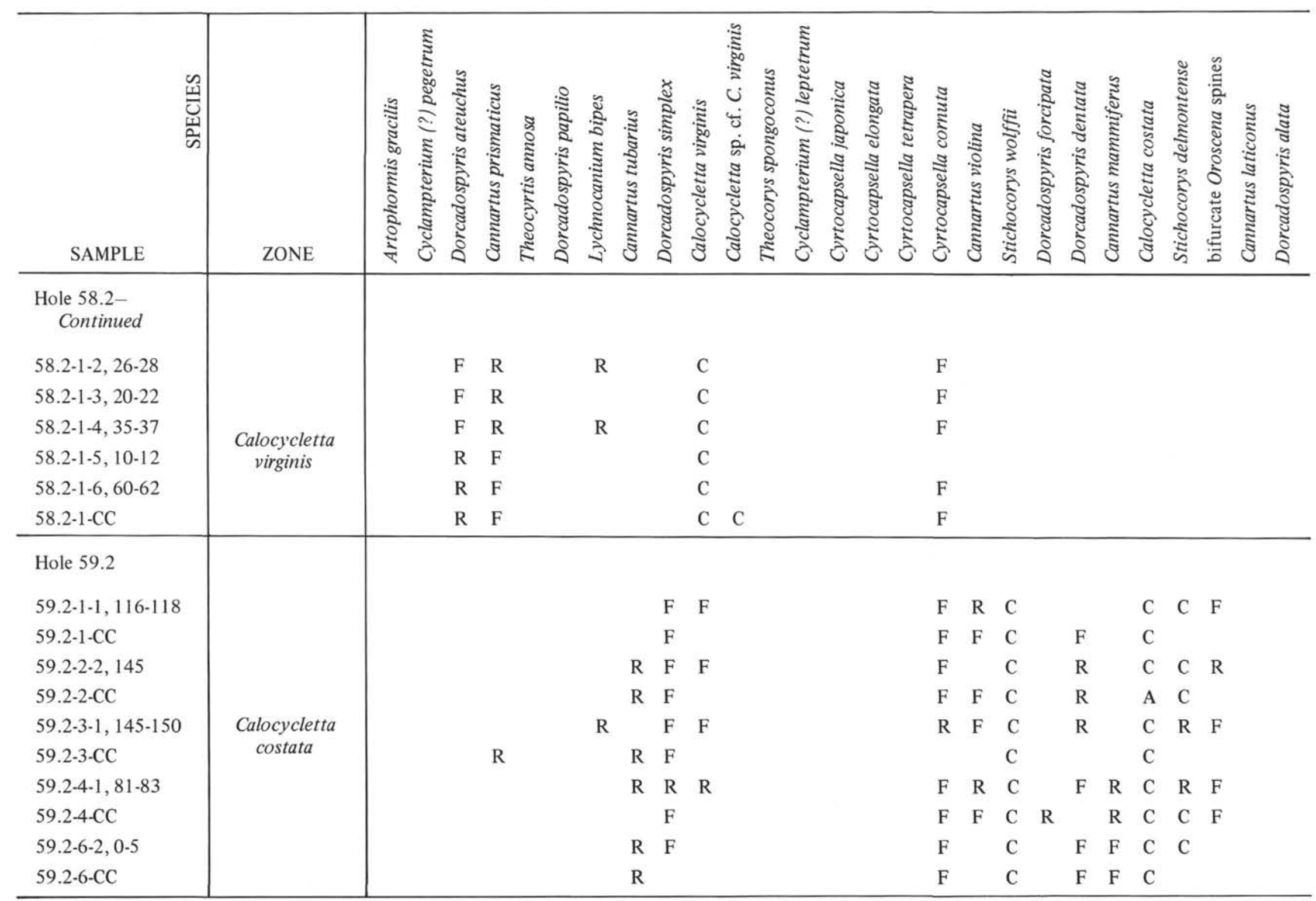


radiolarians, and it is presented in Figure $2^{1}$ with species ranges as given by Riedel and Sanfilippo. Certain conventions regarding the correlation of Riedel and Sanfilippo's zonation with subdivisions of Cenozoic series have been adopted for the sake of convenience in presentation (ihat is, so as not continually to necessitate reporting a zone as, say, "upper or middle Miocene") and for conformity with policy agreed upon by Leg 6 paleontologists. Because the radiolarian zones are correlated with European Cenozoic type sections only indirectly through correlation with calcareous microfossils, the terms "lower," "middle," and "upper" are used informally and not capitalized.

It was initially agreed among Leg 6 paleontologists to regard the foraminiferal Globorotalia kugleri Zone of Bolli (1966) as the highest zone of the Oligocene, taking its top as the Oligocene-Miocene boundary. To approximate this convention, the top of the radiolarian Lychnocanium bipes Zone-correlated in part at least with the Glogorotalia kugleri Zone by Riedel and Sanfilippo (in press)-is taken as the Oligocene-Miocene boundary.

Disagreement of ranges of species in Leg 6 with those given by Riedel and Sanfilippo are dealt with in another section.

Occurrences of Cenozoic Radiolaria in low latitude sites (Sites 53 to 60 ) are shown in Tables 2 and 3 . Conventions on presentation are the same as for the high latitude sites (Table 1).

\subsubsection{Philippine Basin}

Sites 53, 54 and 60 are in the Philippine Basin west of the Mariana Trench and Ridge (inner or Iwo Jima Ridge). They produced samples well-preserved with Cenozoic radiolarians, usually strongly diluted by volcanic ash. Relatively abundant assemblages of late and middle Miocene age were obtained. Samples containing Oligocene to lower Miocene calcareous microfossils contain very rare or no Radiolaria suggesting the general absence in this region of radiolarians older than middle Miocene. The basement here appears to be no older than Oligocene.

Site $53\left(18^{\circ} 02.0^{\prime} \mathrm{N}, 141^{\circ} 11.5^{\prime} \mathrm{E}\right.$; depth 4629 meters)

A single core at Hole 53.2, from about 12 to 22 meters below the ocean floor, contains the youngest radiolarians at Site 53. At the top of the core, the occurrence of Acrobotrys tritubus indicates a position somewhat higher in the upper Miocene Ommatartus antepenultimus Zone than Core 2 of Hole 53.1, the first radio-

\footnotetext{
${ }^{1}$ Subsequent data (Riedel, personal communication) suggest that the top of Dorcadospyris alata and bottom of Cannartus (?) petterssoni are contiguous, thus disputing the existence, as defined, of the Cannartus laticonus Zone which is omitted here.
}

larian-bearing core in that hole, from about 22 to 31 meters below the sea floor. A lower core in Hole 53.1, Core 3, from about 53 to 62 meters below the ocean floor, contains an Ommatartus antepenultimus Zone assemblage at the top with the upper middle Miocene Cannartus (?) petterssoni Zone represented throughout most of the core. Sporadic radiolarian occurrences in Hole 53.0 disagree in age with calcareous fossils and may represent drilling contamination.

Site $54\left(15^{\circ} 36.6^{\prime} \mathrm{N}, 140^{\circ} 18.1^{\prime} \mathrm{E}\right.$; depth 4990 meters) Hole 54.0 contains also $C$. (?) petterssoni Zone assemblages in the top section of Core 1, from about 83 to 85 meters below the ocean floor. The lower part of Core 1 through Core 7 contains assemblages of the lower middle Miocene Dorcadospyris alata Zone from subbottom depths of about 85 to 270 meters.

Site $60\left(13^{\circ} 40.0^{\prime} \mathrm{N}, 145^{\circ} 41.9^{\prime} \mathrm{E}\right.$; depth 3717 meters $)$

Cenozoic Radiolaria are generally rare in samples of ashy sediments from this site, and those in the deeper cores are poorly preserved. One hole (60.0) was drilled, which recovered samples of early and middle Miocene age.

Cores 1 and 2, from about 52 to 70 meters below the sea floor, contain Cannartus laticonus and rare specimens of other species commonly found in the middle Miocene. This is confirmed by the presence of curved, flattened, as well as, bifurcating orosphaerid spines (Friend and Riedel, 1967). At Site 53 curved, flattened spines are nearly confined to the upper middle Miocene Cannartus (?) petterssoni Zone, while evidence from Site 55.0 suggests that bifurcating spines first appear just below the base of the middle Miocene.

Cores $3,4,5$ and 6 contain no Radiolaria.

Core 7, from about 289 to 299 meters below the ocean floor, contains rare incomplete specimens tentatively identified as Stichocorys wolffii, a species found only in the lower Miocene.

Cores 8 and 9 , from about 343 to 348 meters below the ocean floor, contain $S$. wolffii and occasional specimens of $S$. delmontense and Calocycletta costata, suggesting a correlation with the upper lower Miocene zone named for the latter species.

\subsubsection{Caroline Ridge}

Sites $55,56,57$ and 58 from an area southeast of the Mariana Trench on the northern flank of the Caroline Ridge produced ashy oozes of Neogene to Quaternary age. Radiolarians are abundant in sequences from the upper Oligocene (the apparent age of the ocean floor in this area) through middle (or possibly upper) Miocene. Samples dated late Miocene through Pleistocene on the basis of calcareous microfossils generally contain 
no radiolarians of those ages, but they do contain rare reworked middle and lower Miocene specimens.

Site $55\left(09^{\circ} 18.1^{\prime} \mathrm{N}, 142^{\circ} 32.9^{\prime} \mathrm{E}\right.$; depth 2850 meters $)$ Cores from this site provide an excellent sequence of upper Oligocene through middle Miocene radiolarians. Preservation is exceptionally good in calcareous oozes of the lower cores. Cores 1 through 4 , however, from the sediment surface to about 37 meters subsurface, contain only rare radiolarians redeposited from the middle and lower Miocene in sediments of younger age based on calcareous microfossils. No Radiolaria were found in Core 5 , from about 37 to 46 meters below the sea floor.

Core 6 , from about 46 to 55 meters below the sea floor, contains lower and lower middle Miocene species in fair abundance, with similar abundances of curved, flattened orosphaerid spines (Friend and Riedel, 1967). Curved, flattened orosphaerid spines at Site 53 are found in samples no lower than the base of the upper middle Miocene Cannartus (?) petterssoni Zone. This suggests that the sediment in Core 6 was deposited during the time represented by the $C$. (?) petterssoni Zone with a strong admixture of species from the older Miocene.

Core 7 and most of Core 8 , from about 55 to 72 meters below the ocean floor, contain assemblages of the lower middle Miocene Dorcadospyris alata Zone. While the upper part of Core 8 contains only rare reworked specimens, Stichocorys wolffii reappears in Core 7. This may represent the onset of major redeposition that continues upward.

Assemblages from the bottom of Core 8 through Core 10 , from about 72 to 91 meters below the ocean floor, represent the upper lower Miocene Calocycletta costata Zone. Core 11 and most of Core 12, from subsurface depths of about 91 to 111 meters, are in the lower lower Miocene $C$. virginis Zone.

The bottom of Core 12 and Cores 13 and 14, from about 111 to 131 meters below the sea floor, contain radiolarians of the upper Oligocene Lychnocanium bipes Zone.

Site $56\left(08^{\circ} 22.4^{\prime} \mathrm{N}, 143^{\circ} 33.6^{\prime} \mathrm{E}\right.$; depth 2508 meters $)$

Samples from this site contain Cenozoic radiolarian assemblages very similar to those of Site 55 .

Cores 1 through 3 , from about 73 to 101 meters below the sea floor, contain lower Miocene species reworked into sediments dated upper Miocene on the basis of calcareous microfossils.

Most of Core 4, from subbottom depths of about 101 to 108 meters, contains radiolarians including curved, flattened orosphaerid spines representative of the upper middle Miocene Cannartus (?) petterssoni Zone with admixed lower Miocene species.

The lower part of Core 4 and Core 5, from about 108 to 119 meters below the sea floor, contains assemblages of the lower middle Miocene Dorcadospyris alata Zone. Reworked specimens are very rare, except for Stichocorys wolffii, which-as noted in Hole 55.0may range higher in this area.

Cores 6 through 9, from depths of about 187 through 223 meters, contain radiolarians of the upper Oligocene Lychnocanium bipes Zone, as does the centerbit sample raised before attempting Core 11, apparently from a subbottom depth of about 270 meters. Occurrences of Theocyrtis annosa in these $L$. bipes Zone assemblages (and at Site 57) suggest that these samples range lower in the zone than those of the same zone from Site 55 .

Site $57\left(08^{\circ} 40.9^{\prime} \mathrm{N}, 143^{\circ} 32.0^{\prime} \mathrm{E}\right.$; depth 3300 meters)

Samples from two of the three holes drilled at this site contain abundant, well-preserved radiolarian faunas. As at Sites 55 and 56, assemblages are in place in samples older than upper Miocene, but they are lacking or reworked in upper Miocene and younger sediments.

Core 1 of Hole 57.0 contains radiolarians of the upper Oligocene L. bipes Zone, from about 298 to 302 meters below the ocean floor. These are the only samples containing the delicate species Artophormis gracilis. The presence also of Theocyrtis annosa and Dorcadospyris papilio suggests that these cores are older than those with Lychnocanium bipes Zone assemblages from Site 55 , and probably equivalent to those from Site 56 .

The center-bit sample raised before Core 2 of Hole 57.0 , from a presumed depth of 328 meters, also contains species of the L. bipes Zone. Cores 2 and 3 contained basalt.

Core 1 of Hole 57.1 , from about 44 to 53 meters below the sea floor, contains lower Miocene species in samples dated late Miocene on the basis of calcareous microfossils. Cores 2, 3 and 4, from subbottom depths of about 307 to 330 meters, contain species represent ing the $L$. bipes Zone, though radiolarians are rare and poorly preserved in Core 4.

The single core from Hole 57.2 was dated Pliocene on the basis of calcareous microfossils, and it contained no Radiolaria. 
Site $58\left(09^{\circ} 14.1^{\prime} \mathrm{N}, 144^{\circ} 25.1^{\prime} \mathrm{E}\right.$; depth 4503 and 4486 meters)

Samples from this site contain lower Miocene species in one core while two other cores contain reworked lower or middle Miocene specimens in younger sediments.

A small core catcher sample available from Hole 58.0, from about 14 to 20 meters below the ocean floor, contains no Radiolaria.

Radiolaria are very rare in Core 1 of Hole 58.1, from about 0 to 9 meters subbottom. Lower or middle Miocene species were apparently reworked into younger sediments. Traces of sample obtained from depths of about 172 to 173 meters below the sea floor contain no Radiolaria (Cores 2 and 3).

A single core from Hole 58.2, from about 137 to 143 meters below the ocean floor, contains radiolarians of the lower Miocene Calocycletta virginis Zone.

\subsubsection{Abyssal Pacific}

Site 59 is on the deep ocean floor east of the Mariana Trench and is separated from the Caroline Ridge to the south by a fracture zone. Cenozoic radiolarians here are related biogeographically to other equatorial faunas.

Site $59\left(11^{\circ} 46.8^{\prime} \mathrm{N}, 147^{\circ} 34.9^{\prime} \mathrm{E}\right.$; depth 5554 and 5547 meters)

Radiolaria from various Cenozoic horizons occur in samples from one hole. From another hole, lower Miocene radiolarians of variable abundance and preservation are found in brown clays. One core contains a relatively well-preserved Cretaceous assemblage as well.

No samples were recovered from Hole 59.0.

Cores 1 and 2 of Hole 59.1 were also unsuccessful. Core 3 , from about 52 to 61 meters below the sea floor, contains a mixed assemblage with species representative of Quaternary, Miocene, Eocene and Cretaceous strata.

From Hole 59.2 a sequence of six cores from subbottom depths of about 89 through 135 meters was obtained. They all contain species of the upper lower Miocene Calocycletta costata Zone.

\subsubsection{Discussion}

In general, the sequence of radiolarian datum levels in these low latitude Cenozoic samples is similar to that previously reported from equatorial regions with allowances for normal preservation and sampling deficiencies. There are minor differences in the sequence reported here in Tables 2 and 3, but the zones based on these levels by Riedel and Sanfilippo (in press) are applicable, with confidence, to the Leg 6 samples. A few major differences in species ranges warrant attention, however; and, previously undocumented ranges of some species provide potentially new datum levels for future subdivision of the existing zones.

In the upper Miocene Stichocorys delmontense has, until now, appeared to reach extinction at about the level which it evolves into $S$. peregrina at the base of the $S$. peregrina Zone (Figure 2). In the samples from Site 53 (Table 2), S. peregrina appears lower in the section near the base of the Ommatartus antepenultimus Zone, assuming other datum levels are in normal sequence. Both $S$. peregrina and $S$. delmontense appear together throughout much of that zone, but $S$. delmontense reaches its extinction below the top of the $O$. antepenultimus Zone-well below its previously reported last appearance. Thus, it appears that at these latitudes in the western Pacific, $S$. peregrina evolved much earlier than in previously studied regions; and, it persisted with its ancestor $S$. delmontense, which also reaches an earlier extinction here. If, as is suggested, $S$. peregrina first evolved in this region, it is as yet difficult to understand how the sequence observed in other areas originated. Although few samples from the high latitude sites contain $S$. delmontense, the sequence there seems to be as previously reported.

At Sites 54 (Table 2) and 55 (Tables 2 and 3) Stichocorys wolffii ranges above the level of the first appearance of Dorcadospyris alata, its normal extinction level (Riedel and Sanfilippo, in press, Figure 3).

Several species whose ranges have not previously been recorded in detail offer potentially new datum levels for a future subdivision of the radiolarian zonation. These species and the tables in which the limits of their ranges appear are as follows:

1) Spongodiscids, an undescribed elliptical species, appear to evolve from an undescribed circular species-Table 2.

2) Calocycletta sp. cf. C. virginis-Table 3.

3) Theocorys spongoconus-Table 3.

Sanfilippo and Riedel (in press) have recently discussed several genera of closed theoperid radiolarians. Occurrences of several of these species are recorded for samples selected to indicate the possible limits of their ranges in Leg 6 samples. Limited available time did not permit comprehensive treatment of most of these forms. Lithopera spp. are recorded in Tables 1 and 2. Cyclampterium pegetrum and C. leptetrum are recorded in Table 3. C. tanythorax and C. brachythorax were not recognized, but a more thorough search may disclose their presence in these samples. 
As discussed above (Site 55) and in the systematics section, the ranges of two types of orosphaerid spines can be more narrowly estimated in these samples (Tables 2 and 3 ) than in those previously reported by Friend and Riedel (1967).

\section{SYSTEMATICS, CENOZOIC RADIOLARIA}

The systematics in this report follow closely the scheme used by Riedel and Sanfilippo (in press) and Sanfilippo and Riedel (in press) which contain more extensive synonymies for several of the species than are presented here.

\section{Order POLYCYSTINA Ehrenberg}

Polycystina Ehrenberg, 1838, emend. Riedel, 1967b, p. 291.

Suborder SPUMELLARIA Ehrenberg, 1875

Family ACTINOMMIDAE Haeckel

Actinommidae Haeckel, 1862, emend. Riedel, 1967b, p. 294.

Genus Stylatractus Haeckel, 1887

Stylatractus universus Hays (Plate 1, Figure 7):

Stylatractus sp. Hays, 1965, p. 167, Plate 1, Figure 6. Stylatractus universus Hays, in press, Plate 1, Figures 1 and 2.

\section{Genus Druppatractus Haeckel, 1887}

Druppatractus acquilonius Hays (Plate 1, Figures 5 and 6):

Druppatractus acquilonius Hays, in press, Plate 1, Figures 4 and 5.

\section{Genus Cannartus Haeckel, 1881}

Cannartus prismaticus (Haeckel) (Plate 3, Figure 2): Pipettella prismatica Haeckel, 1887 , p. 305 , Plate 39 , Figure 6; Riedel, 1959, p. 287, Plate 1, Figure 1. Cannartus prismaticus Haeckel; Riedel and Sanfilippo, in press, Plate 15, Figure 1.

Cannartus tubarius (Haeckel) (Plate 3, Figure 3):

Pipettaria tubaria Haeckel, 1887, p. 339, Plate 39, Figure 15; Riedel, 1959, p. 289, Plate 1, Figure 2.

Cannartus tubarius (Haeckel); Riedel and Sanfilippo, in press, Plate 15, Figure 2.

Cannartus violina Haeckel (Plate 3, Figure 4):

Cannartus violina Haeckel, 1887, p. 358, Plate 39, Figure 10; Riedel, 1959, p. 290, Plate 1, Figure 3.

Cannartus mammiferus (Haeckel) (Plate 3, Figure 5): Cannartidium mammiferum Haeckel, 1887, p. 375, Plate 39, Figure 16.
Cannartus mammiferus (Haeckel); Riedel, 1959, p. 291, Plate 1, Figure 4.

Cannartus laticonus Riedel (Plate 3, Figure 6):

Cannartus laticonus Riedel, 1959, p. 291, Plate 1, Figure 5 .

Cannartus (?) petterssoni Riedel and Sanfilippo (Plate 3, Figure 8):

Cannartus (?) petterssoni Riedel and Sanfilippo, in press, Plate 14, Figure 3.

Remarks: This species seldom appears in the Leg 6 samples. Specimens recorded from sequences containing relatively large abundances of Ommatartus hughesi are prehaps reworked or are extreme variants of Ommatartus hughesi populations, $O$. hughesi presumably having evolved from C. (?) petterssoni.

\section{Genus Ommatartus Haeckel, 1881}

Ommatartus antepenultimus Riedel and Sanfilippo (Plate 3, Figure 10):

Ommatartus antepenultimus, Riedel and Sanfilippo, in press, Plate 14, Figure 4.

Ommatartus hughesi (Campbell and Clark) (Plate 3, Figure 9):

Ommatocompre hughesi Campbell and Clark, 1944, p. 23, Plate 3, Figure 12.

Ommatartus hughesi (Campbell and Clark); Riedel and Sanfilippo, in press.

\section{Family SPONGODISCIDAE Haeckel}

Spongodiscidae Haeckel, 1862, emend. Riedel, 1967b, p. 295 .

Two undescribed forms referable to the family spongodiscidae have been tabulated in the results presented here because of their potential stratigraphic value, although complete species descriptions are not yet possible. A species referred to in Table 2 as "elliptical spongodiscid" (Plate 1, Figure 10) is a discoidal form, elliptical in outline with a thickened spongy outer zone, a thickened spongy long axial zone joining the outer zone at the ends and separated from it in the short axis by parallel thinner spongy zones. This species may have evolved during the upper Miocene from a discoidal form (Plate 1, Figure 8) called "circular spongodiscid" in Table 2 through an intermediate form illustrated in Plate 1, Figure 9.

\section{Family OROSPHAERIDAE Haeckel, 1887}

\section{Genus Oroscena Haeckel}

Friend and Riedel (1967) point out the stratigraphic significance of species of this genus with spines of certain shapes. During the examination of these samples, 
two forms of detached orosphaerid spines were recorded in Tables 2 and 3. Curved, flattened forms, here called "curved, flat Oroscena spines" (Plate 3, Figure 7), appear to be restricted to the upper middle Miocene (approximately the Cannartus (?) petterssoni Zone). Digitately branched forms, here called "bifurcate Oroscena spines" (Plate 3, Figure 1), are found in upper lower to lower upper Miocene samples.

Suborder NASSELLARIA Ehrenberg, 1875

Family ACANTHODESMIIDAE Haeckel, 1862

Acanthodesmiidae, Haeckel; Riedel, 1967b, p. 296.

Genus Dorcadospyris Haeckel, 1881

Dorcadospyris ateuchus (Ehrenberg) (Plate 4, Figure 6): Ceratospyris ateuchus Ehrenberg, 1873, p. 218. Cantharospyris ateuchus (Ehrenberg); Riedel, 1959, p. 294, Plate 22, Figures 3 and 4.

Dorcadospyris ateuchus (Ehrenberg); Riedel and Sanfilippo, in press, Plate $\$ 5$, Figure 4.

Dorcadospyris papilio (Riedel) (Plate 4, Figure 5):

Hexaspyris papilio Riedel, 1959, p. 294, Plate 2, Figures 1 and 2.

Dorcadospyris papilio (Riedel); Riedel and Sanfilippo, in press, Plate 15, Figure 5.

Dorcadospyris simplex (Riedel) (Plate 4, Figure 1):

Brachiospyris simplex Riedel, 1959, p. 293, Plate 1, Figure 10.

Dorcadospyris simplex (Riedel); Riedel and Sanfilippo, in press, Plate 15, Figure 6.

Dorcadospyris forcipata (Haeckel) (Plate 4, Figure 4): Dipospyris forcipata Haeckel, 1887, p. 1037, Plate 85, Figure 1.

Dipodospyris forcipata Haeckel; Riedel, 1957a, p. 79, Plate 1, Figure 3.

Dorcadospyris forcipata (Haeckel); Riedel and Sanfilippo, in press, Plate 15, Figure 7.

Dorcadospyris dentata Haeckel (Plate 4, Figure 3):

Dorcadospyris dentata Haeckel, 1887, p. 1040, Plate 85, Figure 6; Riedel 1957a, p. 79, Plate 1, Figure 4.

Dorcadospyris alata (Riedel) (Plate 4, Figure 2): Brachiospyris alata Riedel, 1959, p. 293, Plate 1, Figures 11 and 12.

Dorcadospyris alata (Riedel); Riedel and Sanfilippo, in press, Plate 14, Figure 5.

\section{Family THEOPERIDAE Haeckel}

Theoperidae Haeckel, 1881, emend. Riedel 1967b, p. 296.

\section{Genus Theocorys Haeckel, 1881}

Theocorys spongoconus, new species (Plate 5, Figure 6):

Description: Cephalis is subspherical, thick-walled, with rare small pores; it commonly bears a stout, conical horn which is very broad at the base and is very short in some specimens. Thorax is subspherical to pyriform, thick-walled, with circular pores that are framed, giving the surface a rough appearance. Thoracic pores are usually irregularly arranged, but diagonally aligned in some specimens. Thorax terminates in a constricted mouth which is surrounded by the top of the abdomen. Abdomen spongy, inverted conical; it is variable in length but usually as long as the length from apex to termination of thorax; termination irregular; abdomen wall is usually thinner than thoracic wall.

Dimensions: Based on ten specimens from samples 55.0-11-CC and 55.0-12-5, 67 to 69 centimeters: Length to termination of thorax is 100 to $120 \mu$, maximum width is 95 to $108 \mu$, and width of thoracic mouth is 35 to $45 \mu$.

Remarks: The ancestry of this species is not known, but it may be related to such species as Eusyringium lagena (Ehrenberg) and Eusyringium fistuligirum (Ehrenberg) (see Riedel and Sanfilippo, in press, Plate 8, Figures 5 through 9) from which it may have evolved by development of a spongy abdomen from a latticed one.

Holotype: Plate 5, Figure 6; DSDP 6, 55.0-11-CC, England Finder coordinates $030 / 1$, to be deposited in the U.S. National Museum, Washington, D. C.

Genus Lychnocanium Ehrenberg, 1847

Lychnocanium bipes Riedel (Plate 5, Figure 5):

Lychnocanium bipes Riedel, 1959, p. 294, Plate 2, Figures 5 and 6.

Genus Stichocorys Haeckel, 1881

Stichocorys wolffii Haeckel (Plate 2, Figure 5):

Stichocorys wolffii Haeckel, 1887, p. 1479, Plate 80, Figure 10; Riedel, 1957a, p. 92, Plate 4, Figures 6 and 7.

Stichocorys delmontense (Campbell and Clark) (Plate 2, Figure 4):

Eucyrtidium delmontense Campbell and Clark, 1944a, p. 56, Plate 7, Figures 19 and 20; Riedel, 1952, p. 8, Plate 1, Figure 5; Riedel, 1957a, p. 93.

Stichocorys delmontense (Campbell and Clark); Riedel and Sanfilippo, in press, Plate 14, Figure 6.

Stichocorys peregrina (Riedel) (Plate 2, Figure 13):

Eucyrtidium elongatum peregrinum Riedel, 1953, p. 812, Plate 85, Figure 2; Riedel, 1957a, p. 94.

Stichocorys peregrina (Riedel); Riedel and Sanfilippo, in press. 
Stichocorys diploconus (Haeckel) (Plate 2, Figure 6): Cyrtocapsa diploconus Haeckel, 1887, p. 1513, Plate 78 , Figure 6.

Stichocorys diploconus (Haeckel); Sanfilippo and Riedel, in press, Plate 1, Figures 31 and 32.

Remarks: The abundance of this species in Leg 6 samples is not known with confidence. It is illustrated to indicate its presence.

\section{Genus Cyrtocapsella Haeckel, 1887}

Cyrtocapsella tetrapera Haeckel (Plate 2, Figure 3): Cyrtocapsa tetrapera Haeckel 1887, p. 1512, Plate 78, Figure 5; (cf.) Nakaseko, 1955, p. 119, Plate 11, Figure 7.

Cyrtocapsella tetrapera Haeckel; Sanfilippo and Riedel, in press, Plate 1, Figures 16,17 and 18.

Cyrtocapsella cornuta Haeckel (Plate 2, Figure 7):

Cyrtocapsa cornuta Haeckel, 1887, p. 1513, Plate 78, Figure 9.

Cyrtocapsella cornuta Haeckel; Sanfilippo and Riedel, in press, Plate 1, Figures 19 and 20.

Cyrtocapsella elongata (Nakaseko) (Plate 2, Figure 1): Theocapsa elongata Nakaseko, 1963, p. 185, Plate 3, Figures 4 and 5.

Cyrtocapsella elongata (Nakaseko); Sanfilippo and Riedel, in press, Plate 1, Figures 11 and 12.

Cyrtocapsella japonica (Nakaseko) (Plate 2, Figure 2): Eusyringium japonicum Nakaseko, 1963, p. 193, textFigures 20 and 21, Plate 4, Figures 1, 2 and 3. Cyrtocapsella japonica (Nakaseko); Sanfilippo and Riedel, in press, Plate 1, Figures 13, 14 and 15.

\section{Genus Lithopera Ehrenberg, 1847}

Lithopera neotera Sanfilippo and Riedel (Plate 2, Figure 11):

Lithopera neotera, Sanfilippo and Riedel, in press, Plate 1, Figures 24, 25, 26 and 28.

Lithopera bacca Ehrenberg (Plate 2, Figure 12):

Lithopera bacca Ehrenberg, 1872a, p. 314; 1872b, Plate 8, Figure 1; Nigrini, 1967, p. 54, Plate 6, Figure 2; Sanfilippo and Riedel, in press, Plate 1, Figure 29.

Lithopera baueri Sanfilippo and Riedel (Plate 2, Figure 8):

Lithopera baueri, Sanfilippo and Riedel, in press, Plate 2, Figures 1 and 2.

Lithopera thornburgi Sanfilippo and Riedel (Plate 2, Figure 9):

Lithopera thronburgi, Sanfilippo and Riedel, in press, Plate 2, Figures 4, 5 and 6.
Genus Cyclampterium Haeckel, 1887 (?)

Cyclampterium (?) pegetrum Sanfilippo and Riedel (Plate 5, Figure 9):

Cyclampterium (?) pegetrum Sanfilippo and Riedel press, Plate 2, Figures 8, 9 and 10.

Cyclampterium (?) leptetrum Sanfilippo and Riedel (Plate 5, Figures 10 and 11):

Cyclampterium leptetrum Sanfilippo and Riedel, in press, Plate 2, Figures 11 and 12.

Genus Artophormis Haeckel, 1881

Artophormis gracilis Riedel (Plate 5, Figure 7):

Artophormis gracilis Riedel, 1959, p. 300, Plate 2, Figures 12 and 13.

Genus Theocyrtis Haeckel, 1887

Theocyrtis annosa (Riedel) (Plate 5, Figures 1 and 2): Phormocyrtis annosa Riedel, 1959, p. 295, Plate 2, Figure 7.

Theocyrtis annosa (Riedel), Riedel and Sanfilippo, in press, Plate 15, Figure 9.

\section{Genus Calocycletta Haeckel, 1887}

Calocycletta virginis Haeckel (Plate 5, Figure 7):

Calocyclas virginis Haeckel, 1887, p. 1381, Plate 74, Figure 4; Riedel, 1959, p. 295, Plate 2, Figure 8.

Calocycletta costata (Riedel) (Plate 5, Figure 8):

Calocyclas costata Riedel, 1959, p. 296, Plate 2, Figure 9.

Calocycletta sp. cf. C. virginis Haeckel (Plate 5, Figure 3):

This form was figured by Riedel and Sanfilippo (in press, Plate 14, Figure 11). It differs from $C$. virginis principally in having feet which are triangular, shovelshaped, rather than lamellar. The exact limits of the species have not yet been worked out.

Genus Lamprocyclas Haeckel, 1882

Lamprocyclas heteroporos Hays (Plate 1, Figure 1): Lamprocyclas heteroporos, Hays, 1965, p. 179, Plate 3, Figure 1.

Lamprocyclas heteroporos ? Hays, in press, Plate 1, Figure 3.

\section{Genus Eucyrtidium Ehrenberg, 1847}

Eucyrtidium calvertense Martin (Plate 1, Figure 3): Eucyrtidium calvertense Martin, 1904, p. 450, Plate 130, Figure 5; Hays, 1965, p. 181, Plate 3, Figure 4; Hays, in press, Plate 1, Figure 6.

Eucyrtidium matuyamai Hays (Plate 1, Figure 4): Eucyrtidium matuyamai Hays, in press, Plate 1, Figures 7,8 and 9 . 
Eucyrtidium tumidulum Bailey (?) (Plate 1, Figure 2): Eucyrtidium tumidulum Bailey, 1856, p. 5, Plate 1, Figure 11.

Eucyrtidium tumidulum ? Bailey; Hays, 1965, p. 181, Plate 3, Figure 7.

This species bears a lateral cephalic tubule and thus belongs in the family Artostrobiidae Riedel (1967a), but is temporarily retained in this genus until its true generic relationship can be determined.

\section{Family CANNOBOTR YIDAE Haeckẹl}

Cannobotryidae Haeckel, 1881, emend. Riedel, 1967b, p. 296.

Genus Acrobotrys Haeckel, 1881

Acrobotrys tritubus Riedel (Plate 2, Figure 10): Acrobotrys tritubus Riedel, 1957, p. 80, Plate 1, Figure 5 .

\section{MESOZOIC RADIOLARIA}

Mesozoic radiolarians occur in samples from 6 of the 17 sites drilled on Leg 6 . They were generally encountered in or near the bottom of holes associated with cherts or similar silicified rocks which eventually prevented further drilling. Therefore, it was never possible to obtain a sequence of pre-Tertiary radiolarians showing evolutionary changes.

Samples from the high latitude sites $(45,46,49,50,51$, $52)$ are poorly preserved. The original skeletons are replaced and infilled with crystalline silica leaving only the gross external features preserved. Because only external topography is preserved, the specimens from these sites are illustrated with scanning electron micrographs, which offer great advantages in resolution and depth of field for expression of surface features. Specimens were coated with gold-palladium and examined on a Japan Electron Optics Laboratory Company model JSM-II scanning electron microscope. These photos, made from smear mounts, are intended to give a general idea of the state of preservation and the kinds of forms present, and they are not necessarily representative of the most common or important forms.

At present, these poorly preserved forms cannot be identified to the species and seldom to the genus level. Names cannot be used with great precision and the following comments are intended to convey the sense in which taxonomic names were used for shipboard work and retained in the Site Reports and Plate captions. The genus name Dictyomitra is applied to slender, conical multi-segmented forms (Plate 9, Figures 2, 3, 6), which are reasonably similar to Dictyomitra multicostata Zittel and are usually restricted to costate forms. Somewhat less similar forms, which are still costate and include broader conical (Plate 10, Figure 2; Plate 9, Figure 4) shapes, generally assigned to this genus in older literature are designated "Dictyomitra." Nassellarian forms (for example, Plate 11, Figure 2) with a large terminal segment preceded by much smaller segments in a conical portion (often with step-like segment outlines) which have often been referred to the genera Stichocapsa or Dicolocapsa in older literature are designated "Stichocapsa." Forms belonging to the genus Hemicryptocapsa have probably also been included in this "Stichocapsa" group. They appear to be most common in lower Cretaceous and Jurassic assemblages. Spherical or slightly elongate forms with two opposite polar spines are designated Stylosphaera (Plate 10, Figure 3). Spherical forms with regular protuberances of the shell wall are referred to the genus Conosphaera.

While the forms in these poorly preserved assemblages are clearly Mesozoic, it is usually not possible to say with great confidence whether they are Cretaceous or Jurassic.

A sample from Site 59 contains Cretaceous radiolarians of substantially better preservation. Internal structures are preserved and the specimens have been studied and illustrated by standard transmitted light optical techniques. Some specimens appear to be markedly better preserved than the majority, suggesting the possibility that two different horizons are represented in this sample.

Site $45\left(24^{\circ} 15.9^{\prime} \mathrm{N}, 178^{\circ} 30.5^{\prime} \mathrm{W}\right.$; depth 5508 meters $)$

A few specimens of Mesozoic radiolarian forms were obtained from rock fragments, and others can be observed in chert chips from the core catcher sample (the only recovery) from 45.1-3. They include some possible pseudoaulophacids, a group apparently restricted to the Cretaceous. Most of the free specimens are poorly preserved as quartz infillings although some are moderately well-preserved. Some specimens in the chert appear to be pyritized.

Site $46\left(27^{\circ} 53.8^{\prime} \mathrm{N}, 171^{\circ} 26.3^{\prime} \mathrm{E}\right.$; depth 5769 meters $)$

Poorly preserved (quartz infilled) Mesozoic Radiolaria are contained in the following samples:

46.0-1-Top, 0 meters below sea floor;

46.0-1-1, 150 centimeters;

46.0-1-2, 140 to 150 centimeters;

46.0-1-3, Bottom;

46.0-1-4, Bottom;

46.0-1-5, Bottom;

46.0-1-6, Bottom; and,

46.0-1-CC, 9 meters below sea floor. 
The Mesozoic specimens occur in hard rock fragments distributed throughout the soft clays that constitute the bulk of the core, a mixture probably due to the drilling process.

Identifiable forms include Dictyomitra spp. (Plate 9, Figure 6), "Stichocapsa"sp. (Plate 11, Figure 2), and saturnalins with spiny rings (Plate 11, Figure 1). Numerous spherical forms are also present.

Site $49\left(32^{\circ} 24.1^{\prime} \mathrm{N}, 156^{\circ} 35.0^{\prime} \mathrm{E}\right.$; depth 4282 meters $)$

Poorly preserved (quartz infilled) Mesozoic Radiolaria are contained in the following samples:

49.0-2-CC, 18 meters below sea floor;

49.1-1-CC, 11 meters below sea floor; and, 49.1-2-CC, 20 meters below sea floor.

Among identifiable forms are "Stichocapsa" spp. (possibly Plate 11, Figure 3), "Dictyomitra" spp. (Plate 9, Figure 4), Stichomitra (?) sp. (Plate 9, Figure 1), actinommids (Plate 10, Figure 5), spongodiscids, hagiastrins, and spiny-ringed saturnalins. Numerous spherical forms are also present.

Site $50\left(32^{\sim} 24.2^{\prime} \mathrm{N}, 156^{\circ} 36.0^{\prime} \mathrm{E}\right.$; depth 4487 meters)

Poorly preserved (quartz infilled) Mesozoic Radiolaria are contained in the following samples:

50.0-1-CC, 42 meters below sea floor;

50.0-2-CC, 45 meters below sea floor; and,

50.0-4-CC, 36 meters below sea floor.

Identifiable forms include "Dictyomitra" spp. (Plate 9, Figure 3; Plate 10, Figure 2), Stylosphaera spp. (Plate 10, Figure 3), “Stichocapsa” spp. (Plate 11, Figure 4), Pseudoaulophacus sp., Conosphaera sp., spiny-ringed saturnalins, spongodiscids, and hagiastrins. Numerous spherical forms are also present.

The presence of pseudoaulophacids suggests a Cretaceous rather than Jurassic age.

Site $51\left(33^{\circ} 28.5^{\prime} \mathrm{N}, 153^{\circ} 24.3^{\prime} \mathrm{E}\right.$; depth 5981 meters)

The following samples contain poorly preserved (quartz infilled) Mesozoic radiolarians:

51.0-1-CC, 123 meters below sea floor, and

51.0-2-CC, 132 meters below sea floor.

Identifiable forms include Dictyomitra spp., Pseudoaulophacus sp. and spiny-ringed saturnalins. Numerous spherical forms are also present.

The presence of pseudoaulophacids suggests a Cretaceous rather than Jurassic age.

Site $52\left(27^{\circ} 46.3^{\prime} \mathrm{N}, 147^{\circ} 07.8^{\prime} \mathrm{E}\right.$; depth 5744 meters $)$

The following samples contain poorly preserved (quartz infilled) Mesozoic radiolarians:

52.0-7-CC, 64 meters below sea floor;

52.0-8-CC, 65 meters below sea floor;
52.0-9-CC, 66 meters below sea floor; and, 52.0-10-CC, 69 meters below sea floor.

Among identifiable forms are "Dictyomitra" spp., Dictyomitra sp. cf. D. multicostata, "Stichocapsa", spp., and spiny-ringed saturnalins. Numerous spherical forms are also present.

Dictyomitra multicostata and similar forms are probably restricted to the Cretaceous.

Site $59\left(11^{\circ} 46.8^{\prime} \mathrm{N}, 147^{\circ} 34.9^{\prime} \mathrm{E}\right.$; depth 5554 and 5547 meters)

Helen P. Foreman kindly made a preliminary examination of Cretaceous radiolarians from the core catcher sample from Hole 59.2, Core 5. The remarks made here are based mainly on her notes, but the author accepts full responsibility for any errors of statement or interpretation. Based on the following evidence, the sample is judged to be of Campanian age:

1) The similarity of this assemblage to those of a low Santonian sample from Trinidad (Marac 1) and a Santonian-Campanian sample from Cuba (B 191) (sample localities in Foreman, 1968).

2) The presence in this sample of a form (Plate 8, Figure 13) similar to Solenotryma dacryodes described from Maestrichtian-Campanian samples by Foreman, 1968.

3) The presence of the form (Plate 6, Figures 8, 9 and 10) which is common in the Campanian Pierre Shale of South Dakota.

4) The presence of Dictyomitra sp. with expanded third or fourth segment (Plate 8, Figure 2).

This assemblage has many forms in common with one encountered in samples from Leg 4 at Site 24 (Riedel and Sanfilippo, in press, Plates 1, 2 and 3) from the western equatorial Atlantic Ocean.

Further comments on individual forms are included in the captions to Plates 6,7 and 8 .

\section{REFERENCES}

Bolli, H. M., 1966. Zonation of Cretaceous to Pliocene marine sediments based on planktonic foraminifera. Boll. Asoc. Venezolana Geol. Mineria Petrol. 9 (1), 3.

Campbell, A. S., 1954. Radiolaria. In Treatise on Invertebrate Paleontology. R. C. Moore (Ed.). (Univ. Kansas Press and Geol. Soc. Am. Pt. D), Protista 3, 11. 
and Clark, B. L., 1944a. Miocene radiolarian faunas from Southern California, Geol, Soc. Am., Spec, Paper 51. 76 p.

1944b. Radiolaria from Upper Cretaceous of Middle California. Geol. Soc. Am., Spec. Paper 57. $61 \mathrm{p}$.

Ehrenberg, C. G. 1838. Über die Bildung der Kreidefelsen und des Kreidemergels durch unsichtbare Organismen. Kgl. Akad. Wiss. Berlin, Abh., Jahre 1838. 59

1847. Über eine halibiolithische, von Herrn R. Schomburgk entdeckte, vorherrschend aus mikrosckpischen Polycystinen gebildete, Gebirgsmasse von Barbados. Kgl. Preuss. Akad. Wiss. Berlin, Ber., Jahre 1846. 382.

1872a. Midrogeologischen Studienals Zusammenfassung der Beobachtungen des kleinsten Lebens der Meeres Tiefgründe aller Zonen und dessen geologischen Einfluss. Kgl. Preuss. Akad. Wiss. Berlin, Monatsber., Jahre 1872. 265.

Ehrenberg, C. G., 1872b. Mikrogeologische Studien über das kleinste Leben der Meeres-Tiefgründe aller Zonen und dessen geologischen Einfluss. $\mathrm{Kgl}$. A kad. Wiss. Berlin, Abh., Jahre 1872. 131.

1873. Grössere Felsproben des PolycystinenMergels vonBarbados mit weiteren Erläuterungen. Klg. Preuss. Akad. Wiss. Berlin, Ber., Jahre 1873. 213.

1875. Fortsetzung der mikrogeologischen Studien als Gesammt-Uebersicht der mikroskopischen Paläontologie gleichartig analysirter Gebirgsarten der Erde, mit specieller Rücksicht auf den Polysystinen-Mergel von Barbados. Kgl. A kad. Wiss Berlin, Abh., Jahre 1875.

Foreman, H. P., 1966. Two Cretaceous radiolarian genera. Micropaleontology. 12 (3), 355.

1968. Upper Maestrichtian Radiolaria of California. Spec. Paper Paleontol. (Paleaeontol. Assoc., London). (3), $82 \mathrm{p}$.

Friend, J. K. and Riedel, W. R., 1967. Cenozoic orosphaerid radiolarians from tropical Pacific sediments. Micropaleontology. 13 (2), 217.

Frizzell, D. L. and Middour, E. S. 1951. Paleocene Radiolaria from Southeastern Missouri. Bull. Univ. Missouri, Sch. Mines Met. (77), 1.

Goll, R. M., 1969. Classification and phylogeny of Cenozoic Trissocyclidae (Radiolaria) in the Pacific and Caribbean Basins. Part II. J. Paleontol. 43 (2), 322.

Haeckel, Ernst, 1862. Die Radiolarien. (Rhizopoda Radiaria). Berlin (Reimer) 572 p.

1881. Entwurf eines Radiolarien-Systems auf Grund von Studien der Challenger-Radiolarien. Jena Z. Med. Naturwiss. (3), 15, (new series, vol. 8), 418.

1887. Report on the Radiolaria collected by H.M.S. Challenger during the years 1873-76. Rep. Voyage Challenger, Zool. 18, 1803 p.
Hays, J. D., 1965. Radiolaria and Late Tertiary and Quaternary history of Antarctic seas. In Antarctic Research Series 5. Am. Geophys. Union. 125.

(in press). The stratigraphy and evolutionary trends of Radiolaria in North Pacific deep sea sediments. In Geological Investigations in the North Pacific. Geol. Soc. Am. Spec. Paper.

Saito, T., Opdyke, N. D. and Burckle, L. H., 1969. Pliocene-Pleistocene sediments of the equatorial Pacific: their paleomagnetic, biostratigraphic, and climatic record. Bull. Geol. Soc. Am. 80, 1481.

Kozlova, G. E. and Gorbovets, A. N., 1966. Radiolyarii verkhnemelovykh i verkhneeotsenovykh otlozhenii Zapadno-Sibirskoi Nizmennosti. Trudy Vses. Neft. Nauch.-Issled. Geologorazved. Inst. (VNIGRI). (248), $159 \mathrm{p}$.

Lipman, R. Kh., 1960. Radiolaria. In Stratigrafiya i fauna melovykh otlozhenii zapadno-sibirskoi nizmennosti. Min. Geol. SSSR, Tr. Vses, Nauch.-Issled. Geol. Inst. (VSEGEI). 29, 124.

Martin, G. C. 1904. Radiolaria. Marland Geol. Surv. (Miocene). 447

Nakaseko, Kojiro, 1963. Neogene Cyrtoidea (Radiolaria) from the Isozaki Formation in Ibaraki Prefecture, Japan. Osaka Univ. Sci. Rep. (2), 12, 165.

Nigrini, Catherine, 1967. Radiolaria in pelagic sediments from the Indian and Atlantic Oceans. Bull Scripps Inst. Oceanog. Univ. Calif. 11, 1125;

Pessagno, E. A., Jr., 1969. Mesozoic planktonic foraminifera and Radiolaria. In M. N. A. Peterson et al. Initial Reports of the Deep Sea Drilling Project. Vol. 1, Washington, D. C. (U. S. Government Printing Office) 607.

Principi, Paolo, 1909. Contributo allo studio dei Radiolari Miocenici Italiani. Boll. Soc. Geol. Ital. 28, 1.

Riedel, W. R., 1957. Radiolaria: a preliminary stratigraphy. Rep. Swed. Deep-Sea Expend. (3), 6, 59.

1959. Oligocene and Lower Miocene Radiolaria in tropical Pacific sediments. Micropaleontology. 5 (3), 285.

1967a. Some new families of Radilaria. Proc. Geol. Soc. London, (1640), 148.

1967b. Subclass Radiolaria. In The Fossil Record. W. B. Harland et al. (Eds.). London (Geol. Soc. London), 291.

(in press a). Systematic classification of polycystine Radiolaria. In The Micropaleontology of Oceans. B. M. Funnell and W. R. Riedel (Eds.) Cambridge (Cambridge Univ. Press).

(in press b). Occurrence of pre-Quaternary Radiolaria in deep-sea sediments. In The Micropaleontology of Oceans. B. M. Funnell and W. R. Riedel (Eds.). Cambridge (Cambridge Univ. Press).

and Foreman, H. P., 1961. Type specimens of North American Radiolaria. J. Paleontol. 35 (3), 628. 
and Sanfilippo, A., (in press). Radiolaria. In R. Boder et al. Initial Reports of the Deep Sea Drilling Volume 4. Washington, D. C. (U.S. Government Printing Office).

Sanfilippo, A. and Riedel, W. R. (in press). Post-Eocene "closed" theoperid radiolarians. Micropaleontology.

Strelkov, A. A. and Lipman, R. Kh., 1959. Podklass Radiolaria. Sistematicheskaya Chast. In Osnovy Paleontologii. Yu. A. Orlov (Ed.). Moscow (Izdatelstvo Akad. Nauk SSSR). Obshchaya chast, Prosteishie, 426.

\section{EXPLANATION OF PLATES}

Unless otherwise noted, figures on the plates are optical photographs made with transmitted light.

Following specimen identification, the DSDP sample number is given. Slide numbers are given in cases where there is more than one slide for a given sample. Specimens are located on slides by means of England Finder coordinates (Riedel and Foreman, 1961). The England Finder slide is always used with its label to the observer's left. The letter following the England Finder coordinates indicates whether the specimen slide label was to the observer's left (L) or right (R). 


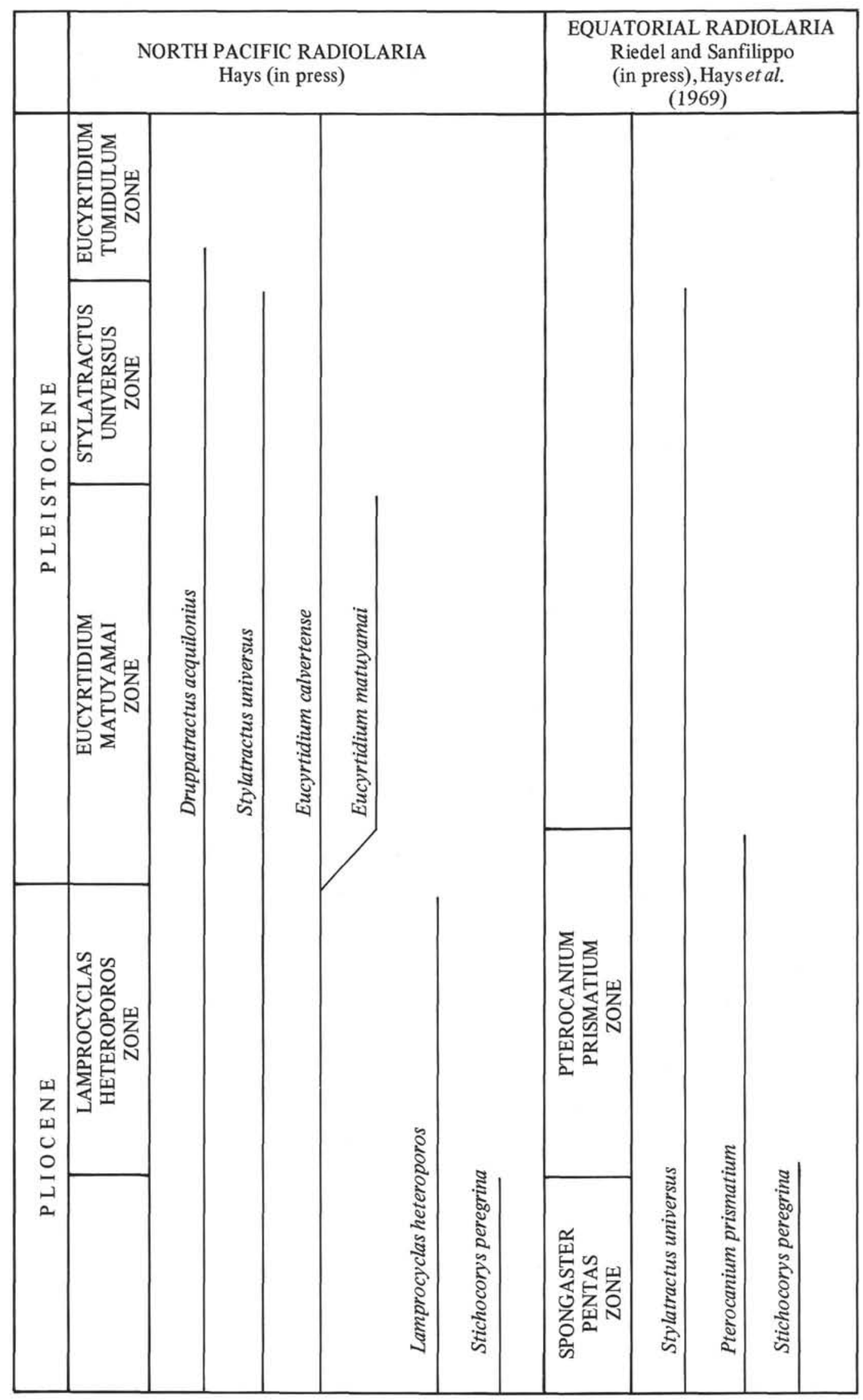

Figure 1. North Pacific Radiolarian Zones After Hays, in press. 
Бे

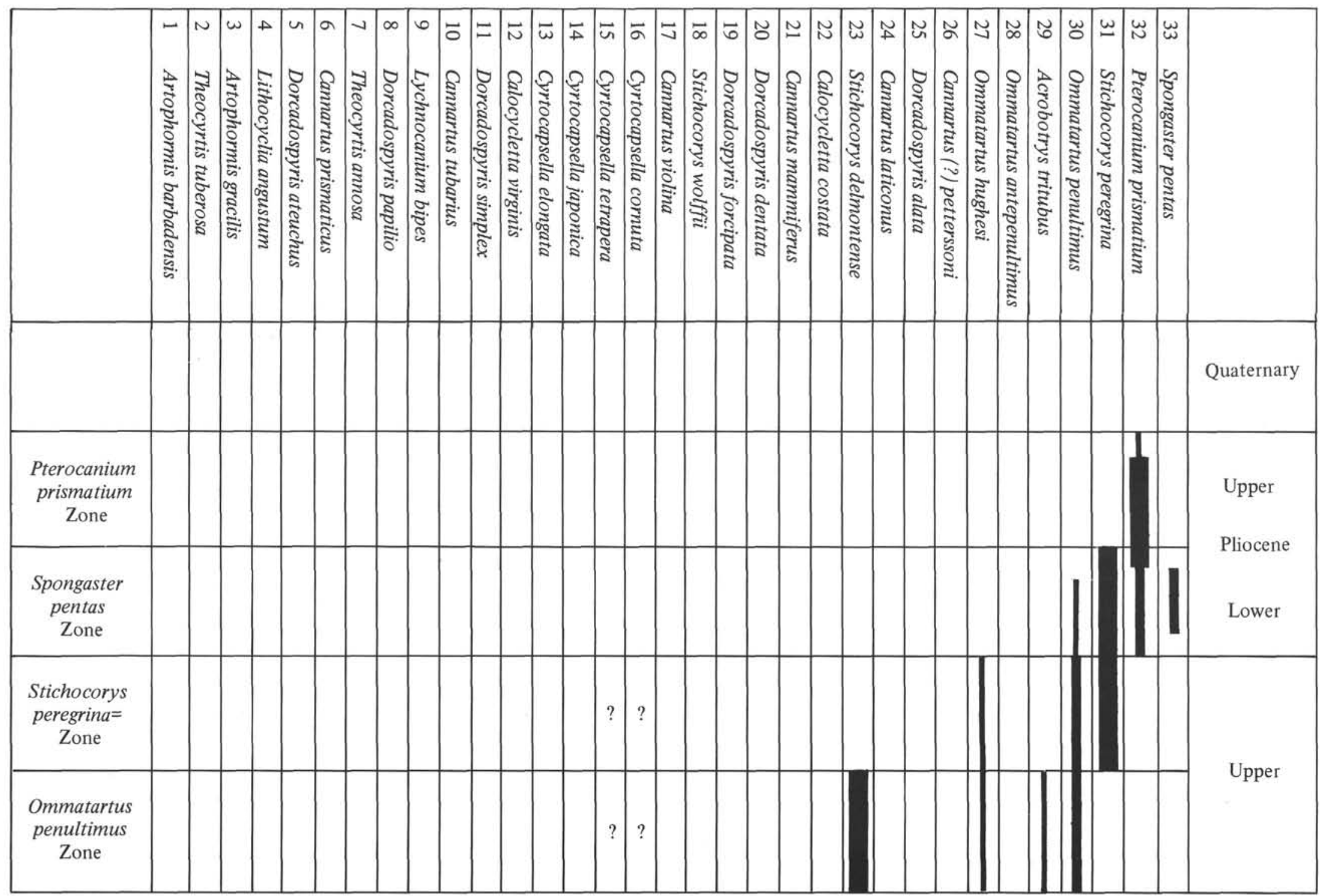

Figure 2. 


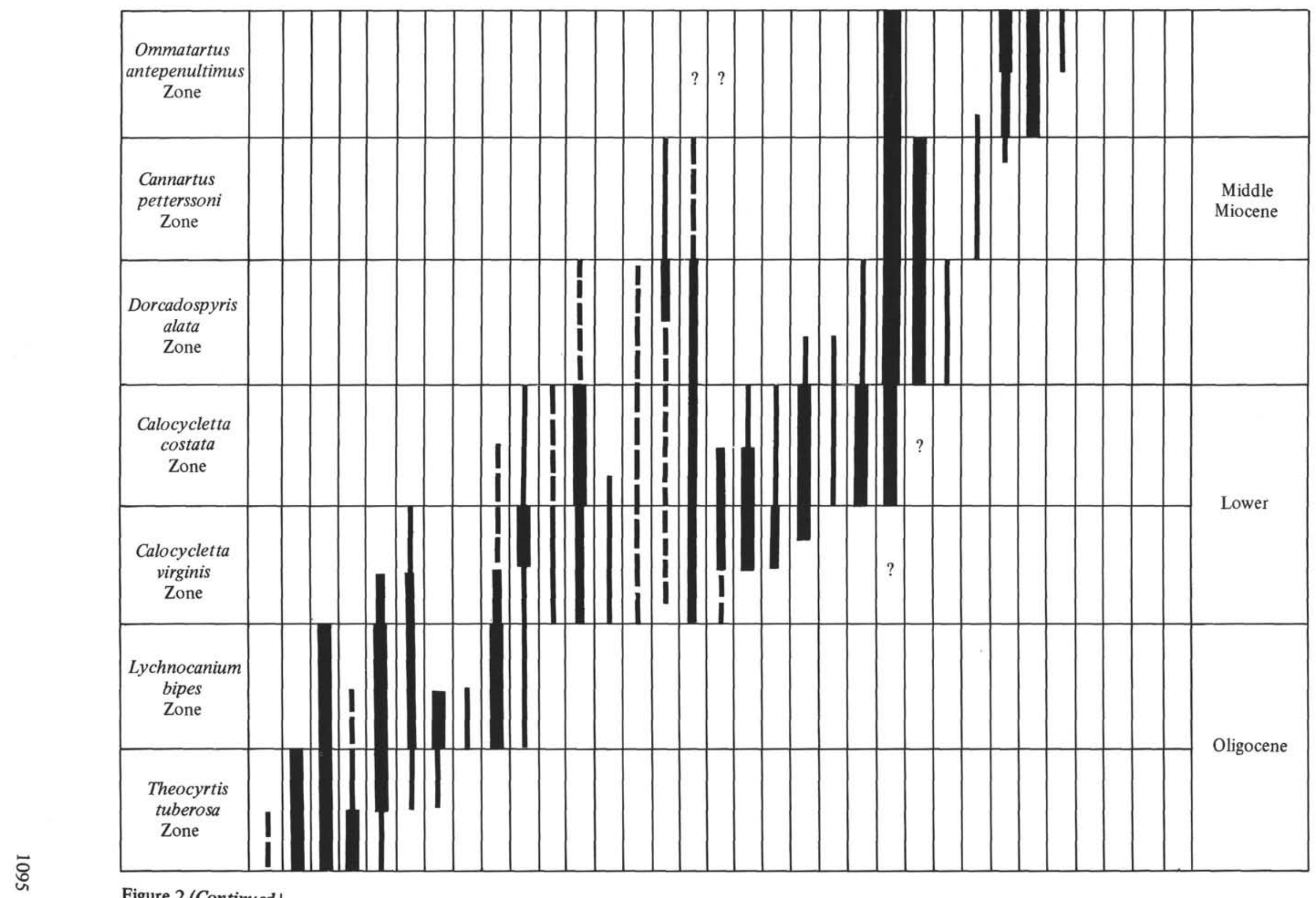

Figure 2(Continued). 


\section{PLATE 1}

Cenozoic Radiolaria

Figure 1 Lamprocyclas heteroporos. 47.2-2-5, 16-18; P 24/2, R. $\times 225$

Figure 2 Eucyrtidium tumidulum. 47.2-2-5, 16-18; O 29/1, R. $\times 225$

Figure 3 Eucyrtidium calvertense. 47.2-2-5, 16-18; P 30/1, R. $\times 225$

Figure $4 \quad$ Eucyrtidium matuyamai. 51.1-1-1, 2-4; L 46/3, R. $\times 225$

Figures 5,6 Druppatractus acquilonius. 47.2-2-3, 71-73; X225 5: N 42/0, R.

6: D $34 / 3, \mathrm{R}$.

Figure $7 \quad$ Stylatractus universus. 47.2-3-3, 71-73; V 34/3, R. $\times 225$

Figures 8, 9, 10 Spongodiscids, genn. et spp. indet. $\times 140$

8: "Circular spongodiscid." 53.2-1-Bottom; B 44/3, $\mathrm{R}$.

9: $53.2-1-5,11-13 ; \mathrm{T} 48 / 3$.

10: "Elliptical spongodiscid." 53.2-1-3, 13-15; T 38/4. 

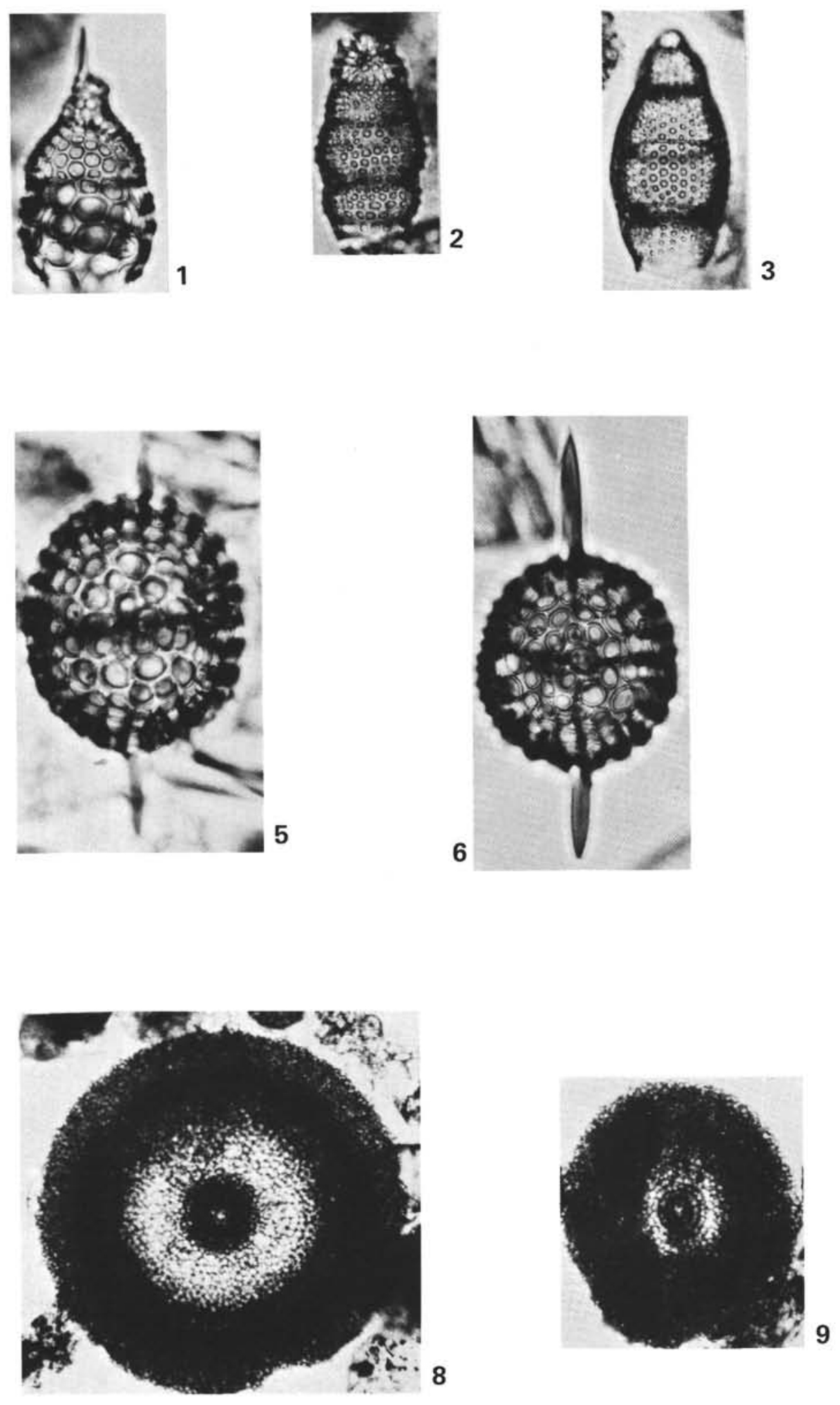
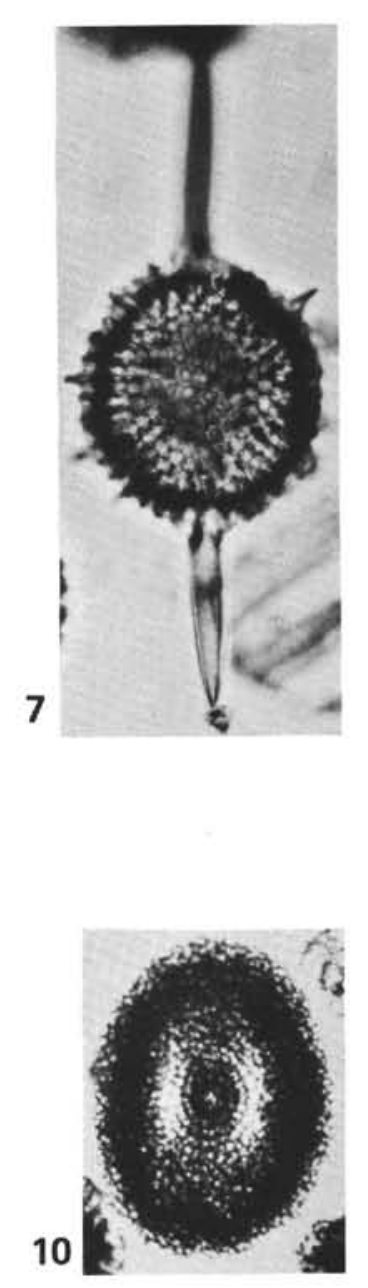


\section{PLATE 2}

Cenozoic Radiolaria

Magnifications $\times 225$

Figure 1

Figure 2

Figure 3

Figure 4

Figure 5

Figure 6

Figure 7

Figure 8

Figure 9

Figure 10

Figure 11

Figure 12

Figure 13

Cyrtocapsella elongata. 55.0-12-3, 85-87; E 30/0, R. Cyrtocapsella japonica. 55.0-12-5, 67-69; V 47/0, R. Cyrtocapsella tetrapera. 55.0-12-5, 67-69; O 49/0, R. Stichocorys delmontense. 53.2-1-Bottom; O 58/1, R. Stichocorys wolffii. 55.0-11-1, 90-92; R 52/0, R. Stichocorys diploconus. 55.0-9-CC; F 28/0, R.

Cyrtocapsella cornuta. 55.0-11-1, 90-92; Z 66/0, R. Lithopera baueri. 54.0-2-1, 32-34; H 63/3, R.

Lithopera thornburgi. 54.0-1-Top; D 23/0, R. Acrobotrys tritubus. 53.2-1-2, 23-25; V 36/3, R. Lithopera neotera. 54.0-2-1, 32-34; D 37/0, R. Lithopera bacca. 47.2-2-5, 16-18; W 30/4, R. Stichocorys peregrina. 47.2-5-3, 16-18; R 32/1, R. 

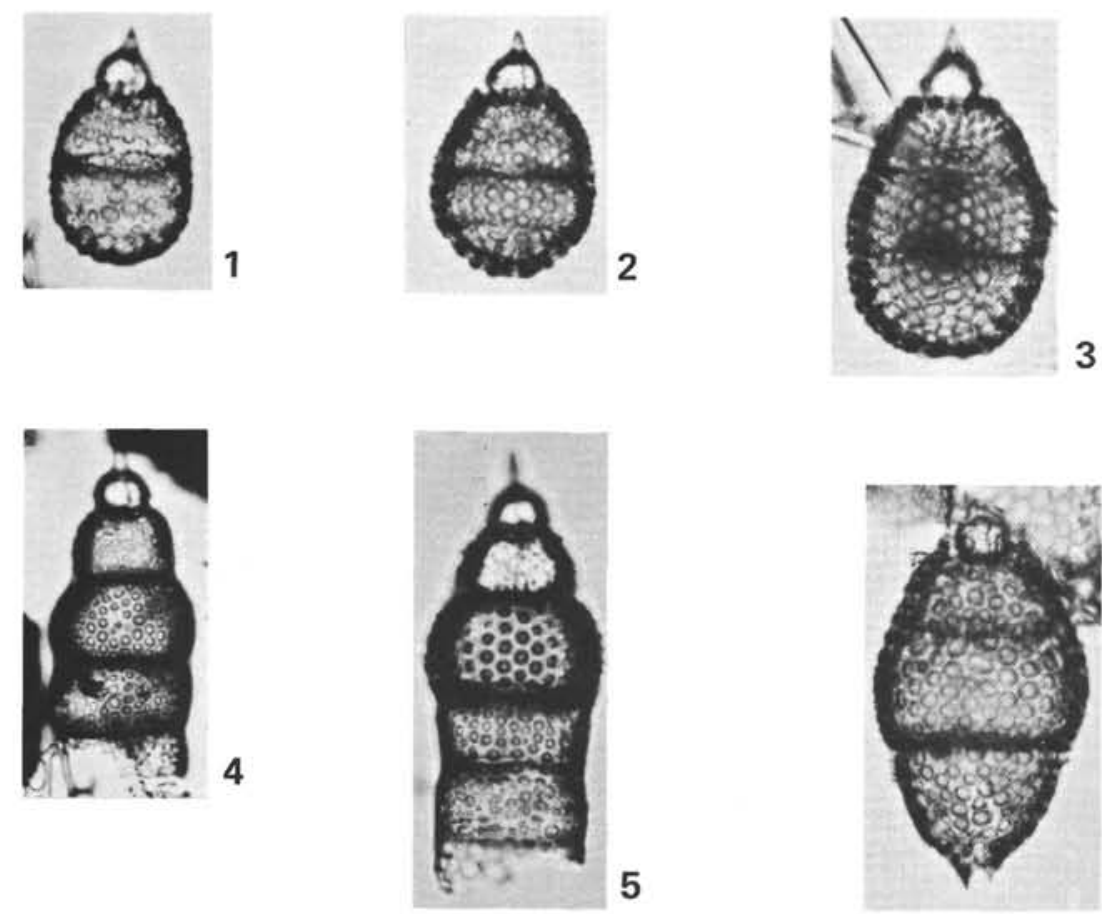

5
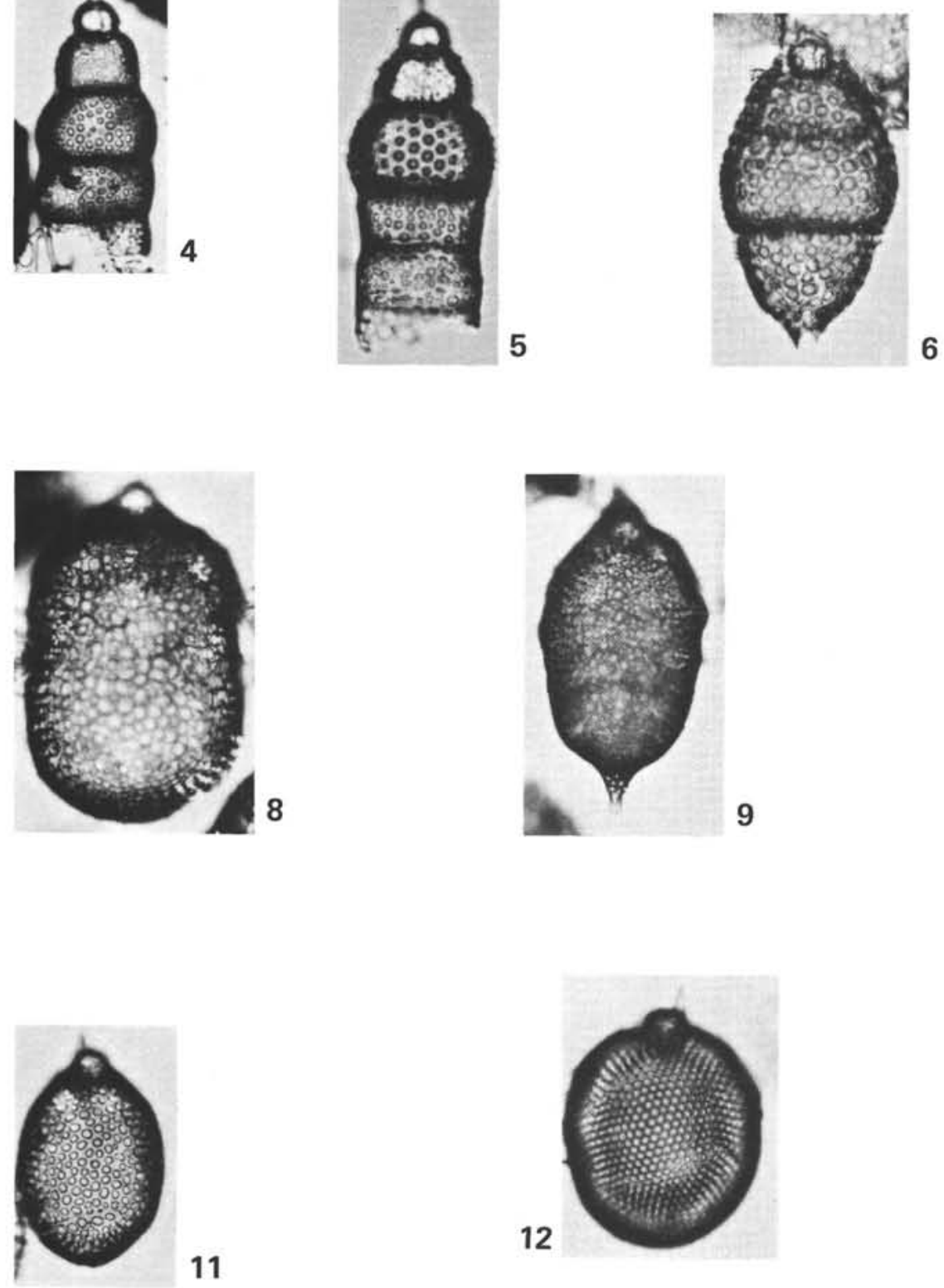
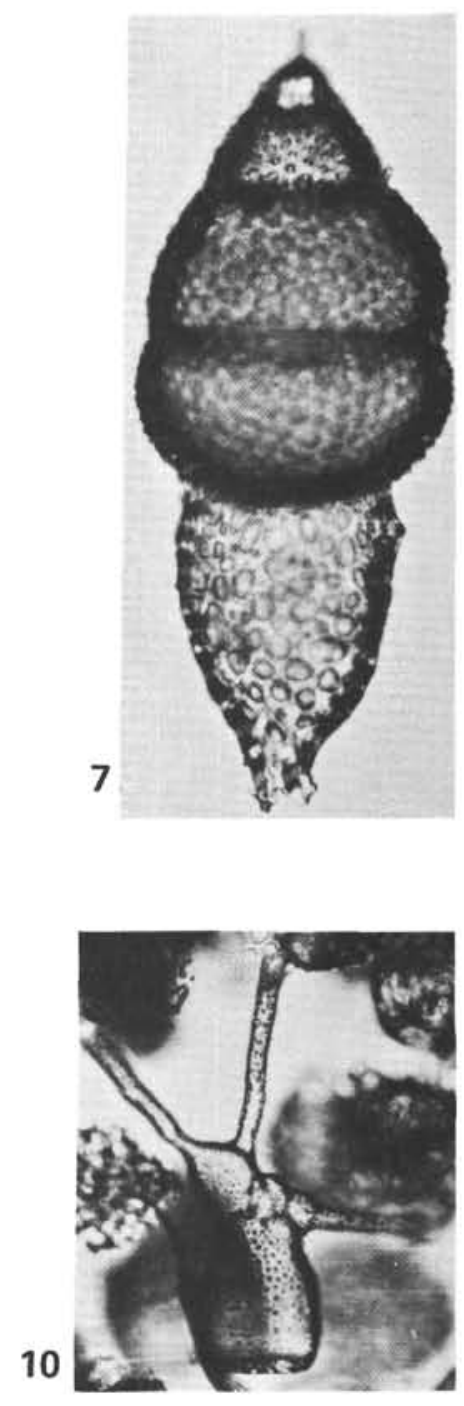

9

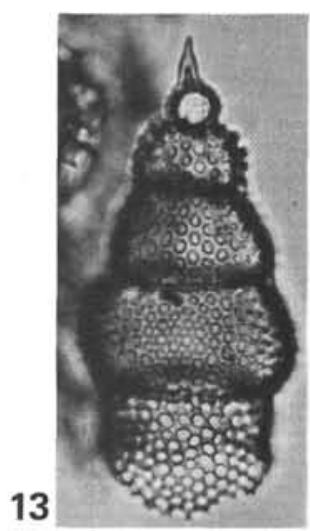


PLATE 3

Cenozoic Radiolaria

Figure 1 Bifurcate Oroscena spine. 55.0-6-1, 18-20; K 51/0, R. $\times 140$

Figure 2 Cannartus prismaticus. 55.0-11-1, 90-92; Q 56/0, R. $\times 225$

Figure 3 Cannartus tubarius. 55.0-10-3, 76-78; N 41/2, R. X225

Figure $4 \quad$ Cannartus violina. 55.0-10-2, 76-78; P 30/0, R. X225

Figure 5 Cannartus mammiferus. 55.0-10-3, 76-78; Y 65/2, R. $\times 225$

Figure 6 Cannartus laticonus. 55.0-7-5, 5-7; W 71/4, R. X225

Figure 7 Curved, flat Oroscena spine. 55.0-6-1, 18-20; T 37/3, R. $\times 140$

Figure 8 Cannartus (?) petterssoni. 53.2-1-Bottom; V 43/0, R. $\times 225$

Figure 9 Ommatartus hughesi. 53.2-1-Bottom; P 46/0, R. X225

Figure $10 \quad$ Ommatartus antepenultimus. 53.2-1-Bottom; C 29/1, R. $\times 225$ 

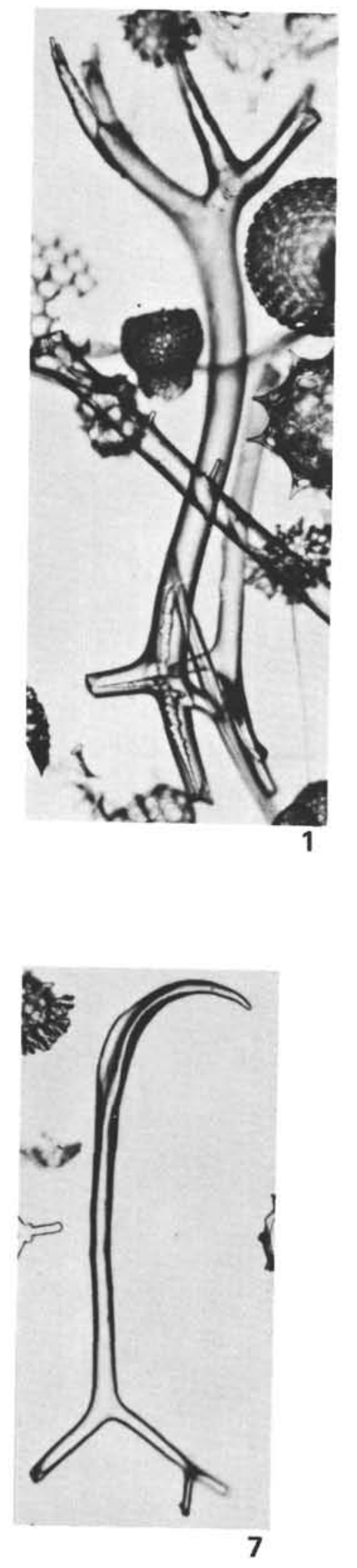
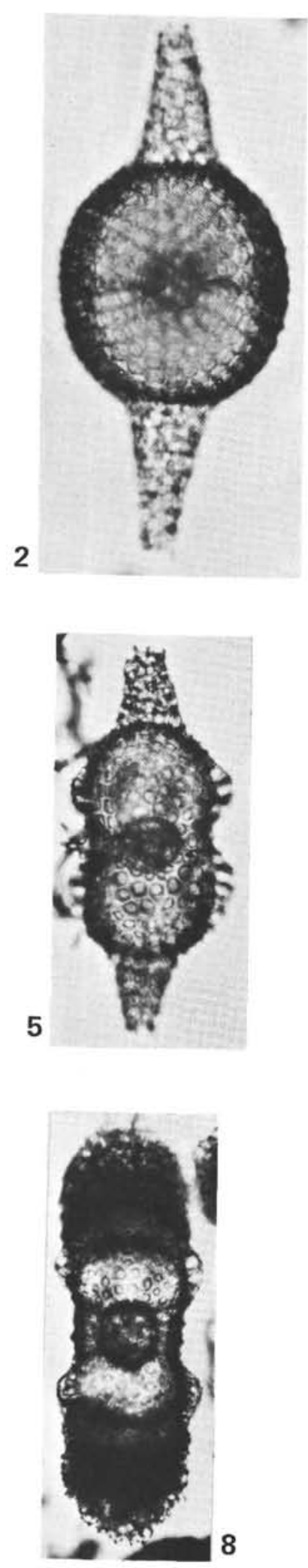
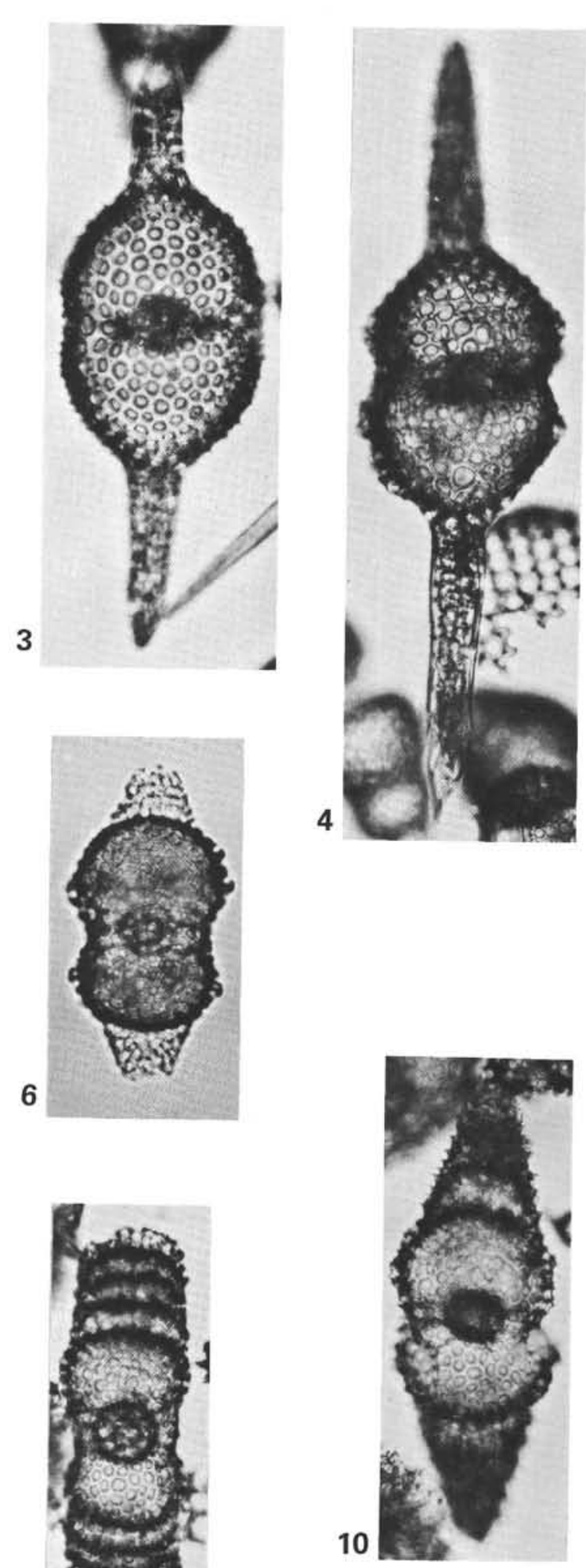


\section{PLATE 4}

Cenozoic Radiolaria

Magnifications $\times 140$

Figure 1

Figure 2

Figure 3

Figure 4

Figure 5

Figure 6 Dorcadospyris simplex. 55.0-10-3, 76-78; X 37/2, R. Dorcadospyris alata. 55.0-6-CC; V 48/1, R. Dorcadospyris dentata. 55.0-9-CC; P 41/2, R. Dorcadospyris forcipata. 55.0-10-3, 76-78; V 69/4, R. Dorcadospyris papilio. 57.1-2-1, 104-106; U 47/1, R. Dorcadospyris ateuchus. 57.1-2-1, 104-106; J 29/0, R. 

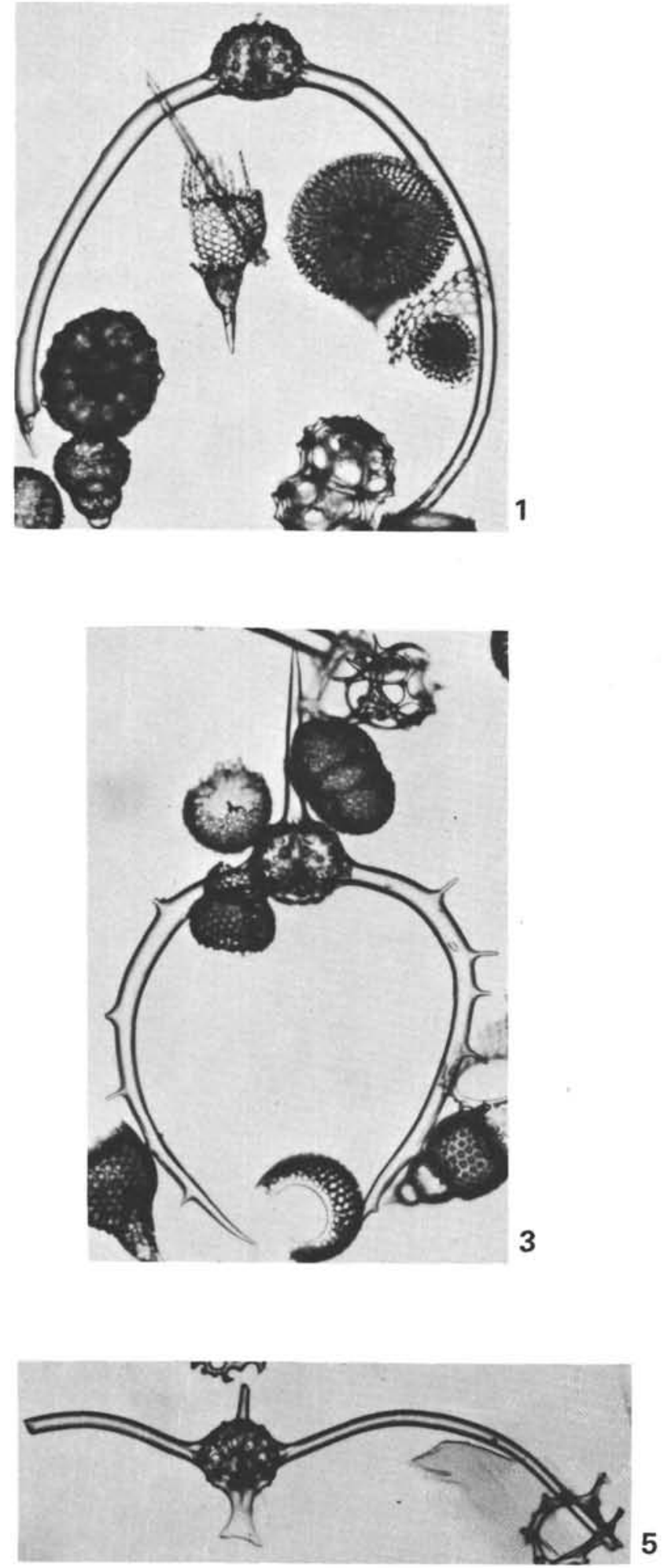
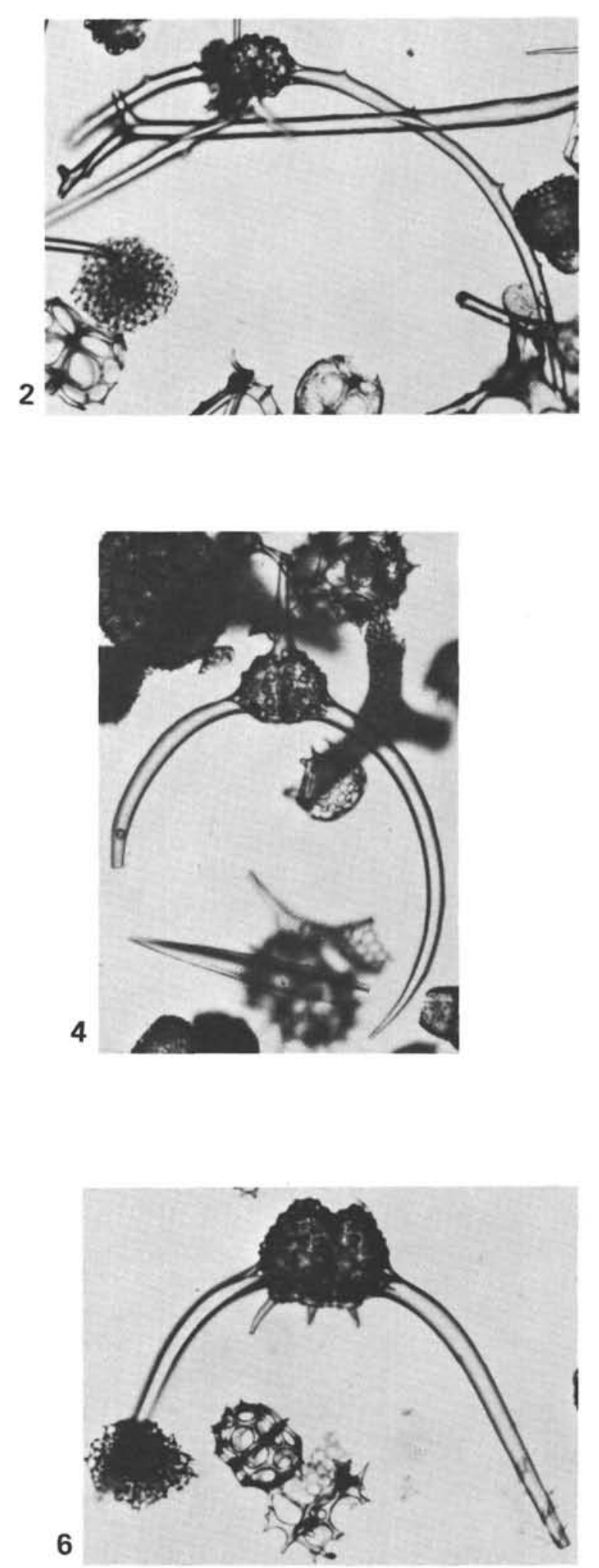


\section{PLATE 5}

\section{Cenozoic Radiolaria}

Figures 1,2 Theocyrtis annosa.

1: $57.0-1-\mathrm{CB} ; \mathrm{S} 20 / 2$, R. X225

2: 57.1-2-1, 104-106; T 59/4, R. X225

Figure $3 \quad$ Calocycletta sp. cf. C. virginis. 55.0-13-1, 77-79; N $31 / 1$, R. $\times 225$

Figure 4 Calocycletta virginis. 55.0-11-1, 90-92; X 10/3, L. $\times 225$

Figure $5 \quad$ Lychnocanium bipes. 55.0-11-CC; T 56/0, R. X225

Figure 6 Theocorys spongoconus, n. sp. Holotype, 55.0-11-CC; O $30 / 1$, R. $\times 255$

Figure 7 Artophormis gracilis. 57.0-1-CB; Y 19/2, R. X255

Figure $8 \quad$ Calocycletta costata. 55.0-10-2, 76-78; N 25/2, R. $\times 225$

Figure 9 Cyclampterium pegetrum. 55.0-12-5, 67-69; J 22/0, R. $\times 140$

Figure $10 \quad$ Cyclampterium leptetrum. 10: $55.0-10-3,76-78 ; 050 / 0$, R. $\times 140$

11: 55.0-10-2, 76-78; Y 64/3, R. X140 

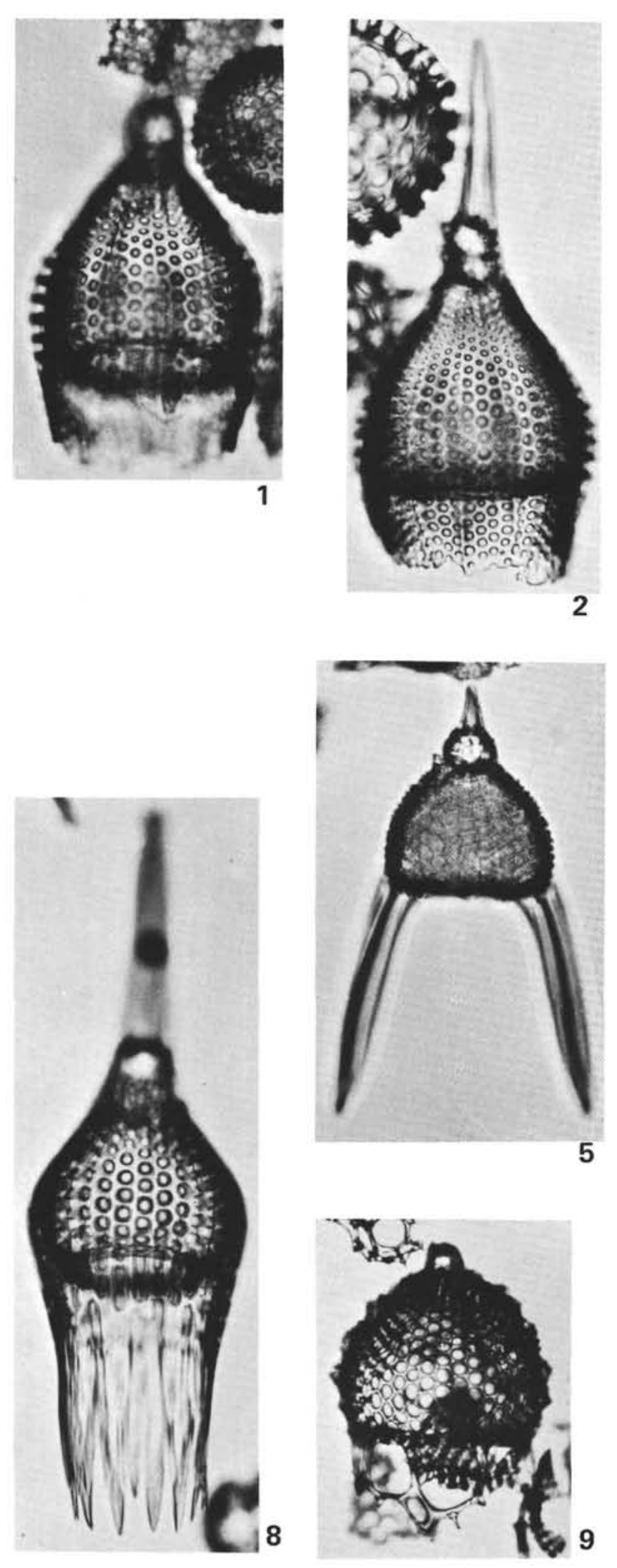
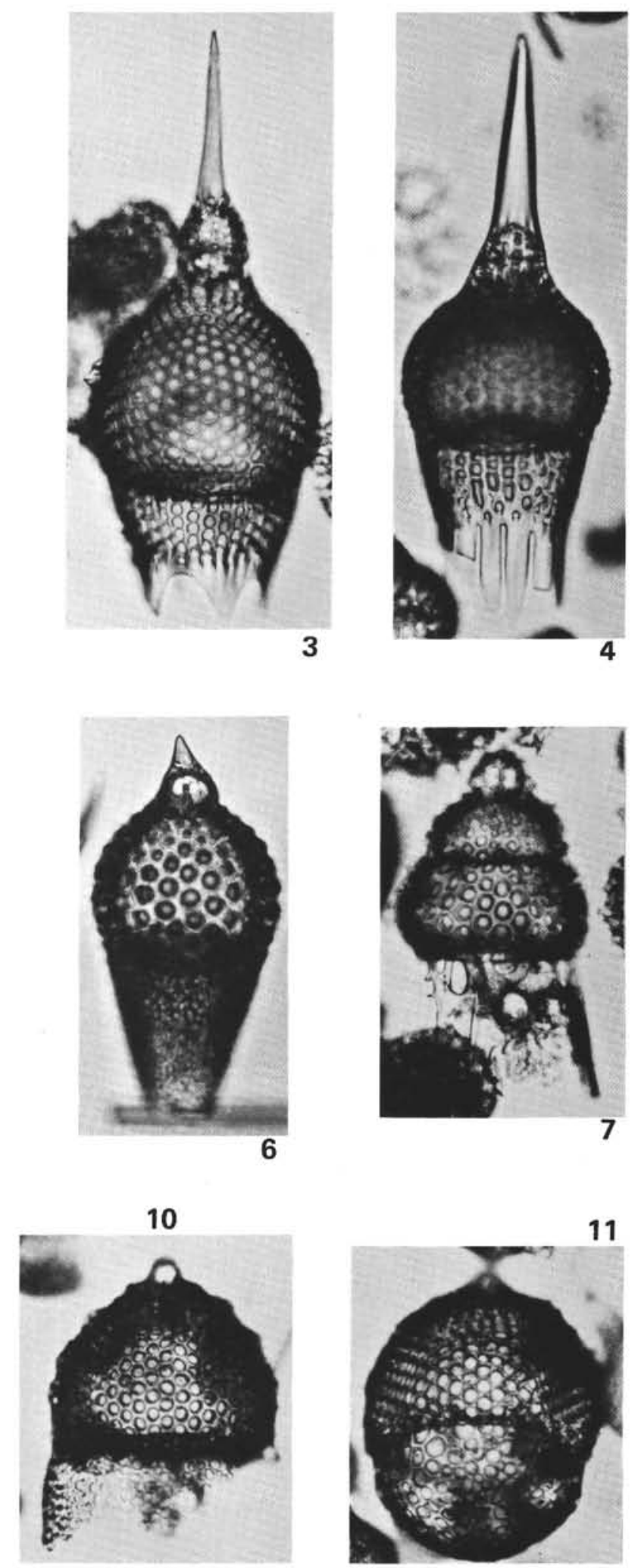


\section{PLATE 6}

Cretaceous Radiolaria from 59.2-5-CC

Magnifications $\times 225$ unless otherwise noted.

Figure 1 Saturnalin, gen. et sp. indet. Slide 2, S 24/4, R.

Figure 2 Conosphaera (?) sp. Slide 3, O 54/4, R.

Figures 3, 4, 5 Actinommids, genn. et spp. indet.

3: Slide 3, H 53/4, R.

4: Slide 3, P 49/0, R.

5: Slide 3, D 48/3, R. Cf. Riedel and Sanfilippo, in press, Plate 1, Figure 1.

Figures 6, 7, 8, Spongodiscids, genn. et spp. indet.

9,10

6: Slide 3, V 54/4, R. Cf. Riedel and Sanfilippo, in press, Plate 1, Figure 8

7: Slide 3, G 42/4, R.

8, 9: Slide 3, D 29/2, R. Note concentric spherical structure, cf. Spongodiscus multus Koslova 1966 in Koslova and Gorbovets, 1966.

10: Slide 3, D 54/1, R. Cf. 8, 9; concentric structure not as well developed in this specimen.

Figure 11 Amphibrachium sp. cf. A. concentricum Lipman, 1960. Slide 3, D 28/2, R.

Figure 12 Hagiastrin, gen. et sp. indet. Slide 2, U 63/2, R. No obvious pseudoaulophacid structure as suggested by Riedel and Sanfilippo, in press, Plate 2, Figures 6 and 7.

Figures 13,14 Pseudoaulophacus superbus (Squinabol) (=P. gallowayi White). Slide 3, S 49/0, R. 14: ×360. 

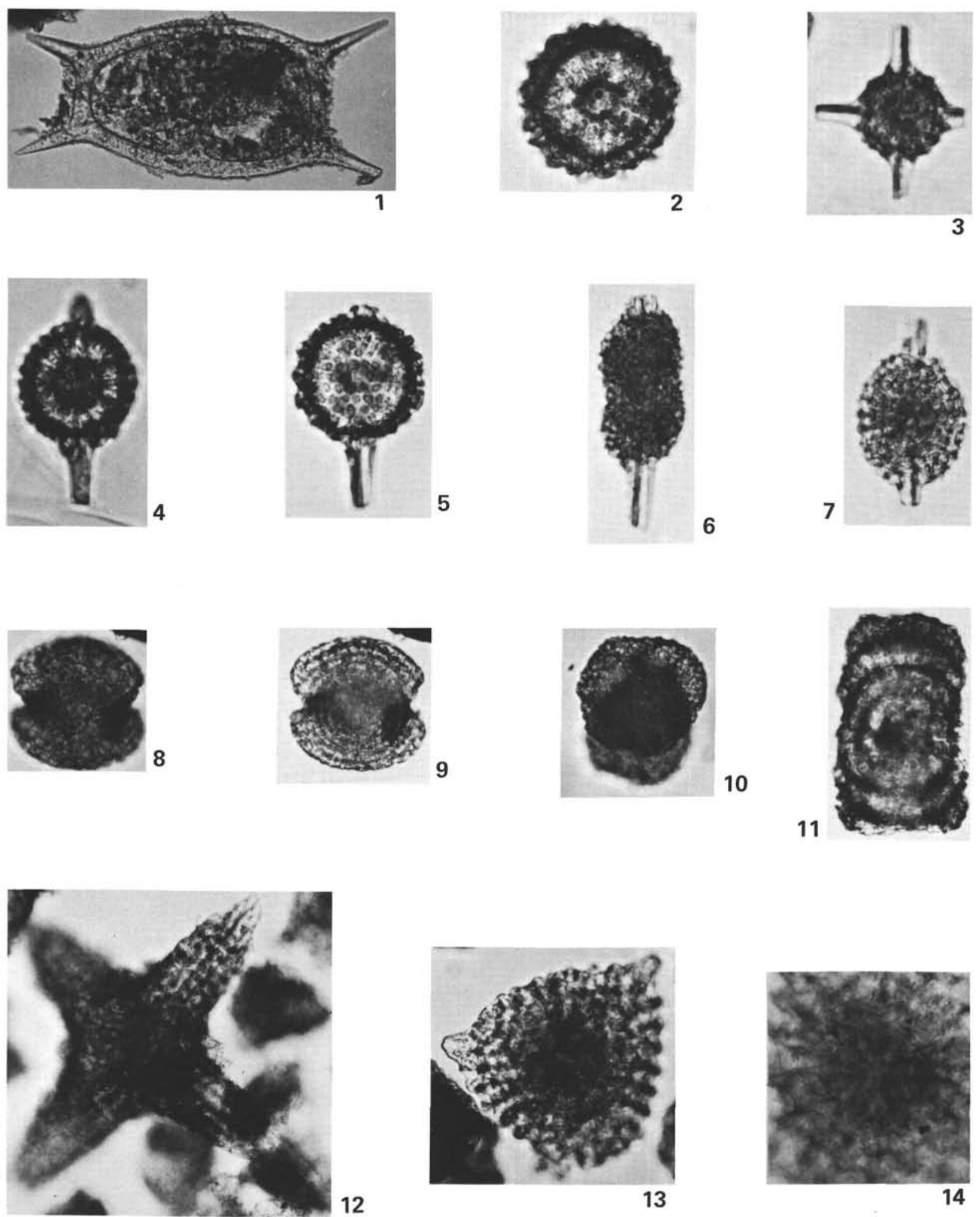


\section{PLATE 7}

Cretaceous Radiolaria from 59.2-5-CC

Magnifications $\times 225$

Figures 1, 2, 3, Theocampe spp.

4, 5, 9 1: Slide 3, K 24/0, R.

2, 3, 4: Cf. Riedel and Sanfilippo, in press, Plate 3, Figure 9.

2: Slide $1, \mathrm{R} 8 / 4, \mathrm{~L}$.

3: Slide 3, K 24/2, R.

4: Slide $1, \mathrm{~J} 16 / 1, \mathrm{~L}$.

5: Slide $1, \mathrm{~V} 31 / 0, \mathrm{~L}$.

Figures 6, 7, 10, Theocapsomma spp.

11 6: Slide 3, W 56/0, R.

7: Slide 3, V 60/1, R.

10: Slide 2, F 56/0, R.

11: Slide 1, B 20/1, L.

Figure 8

Artostrobiid, gen. et sp. indet. Slide 1, U 48/0, R. Cf. Riedel and Sanfilippo, in press, Plate 3, Figure 13.

Figure 12 Cryptocapsa (?) sp. Slide 3, W 56/0, R.

Figure 13 Hemicryptocapsa sp. Slide 3, E 55/3, R.

Figure 14 Gongylothorax verbeeki (Tan Sin Hok). Slide 1, Q $13 / 4$, L.

Figure 15 Spongodiscid, gen. et sp. indet. Slide 3, E 31/2, R. 

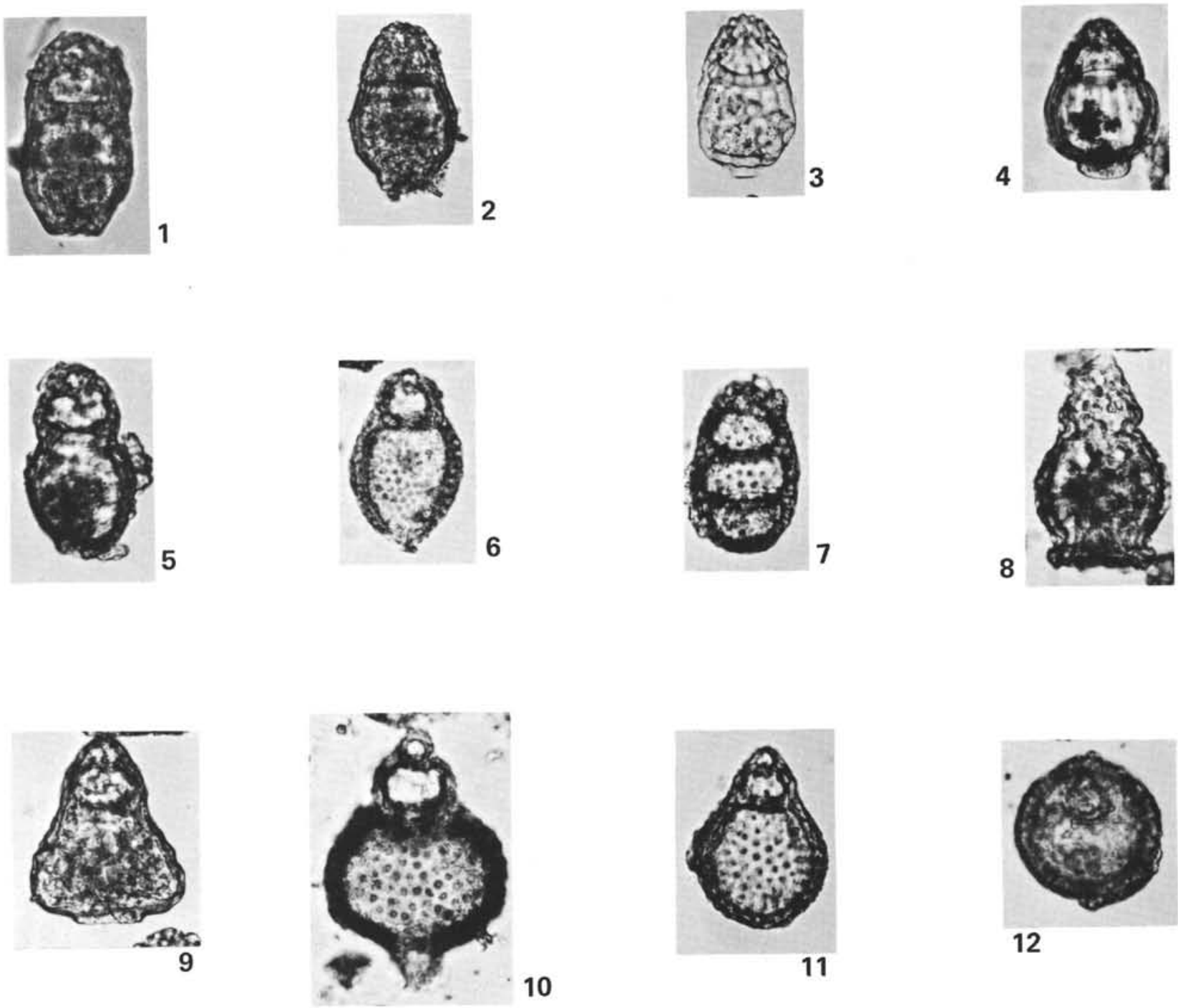

12

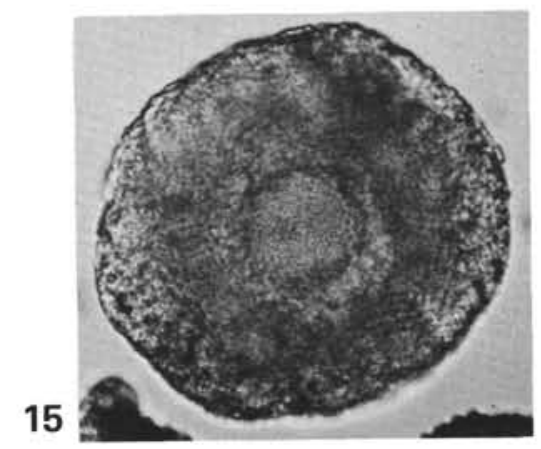




\section{PLATE 8}

Cretaceous Radiolaria From 59.2-5-CC

Magnification $\times 225$

Figures 1, 2, 4 Dictyomitra spp.

1: Slide 3, F 64/4, R.

2: Slide 3, C 47/4, R.

4: Slide 3, V 60/1, R.

Figures 3, $5 \quad$ Stichomitra sp. cf. S. compsa Foreman, 1968.

3: Slide 3, U 67/0, R.

5: Slide $3, \mathrm{H} 66 / 1, \mathrm{R}$.

Figure $6 \quad$ Stichomitra sp. Slide 3, R 52/4, R.

Figures 7,8 Theoperids, gen. et spp. indet.

7: Slide 3, T 64/1, R.

8: Slide $1, \mathrm{U} 48 / 0, \mathrm{R}$.

Figures 9, 10, Amphipyndax sp. cf. A. stocki (Campbell and Clark), 11,12 1944b.

9: Slide 3, F 38/3, R.

10: Slide 3, D 42/0, R.

11: Slide 3, L 65/0, R.

12: Slide $2, \mathrm{~L} 43 / 0, \mathrm{R}$.

Figure 13 Solenotryma sp. cf. S. dacryodes Foreman, 1968. Slide $2, \times 32 / 0, \mathrm{~L}$.

Figure $14 \quad$ Solenotryma sp. Slide 3, X 55/4, R.

Figure 15 Theoperid, gen. et sp. indet. Slide 3, D 49/4, R. 

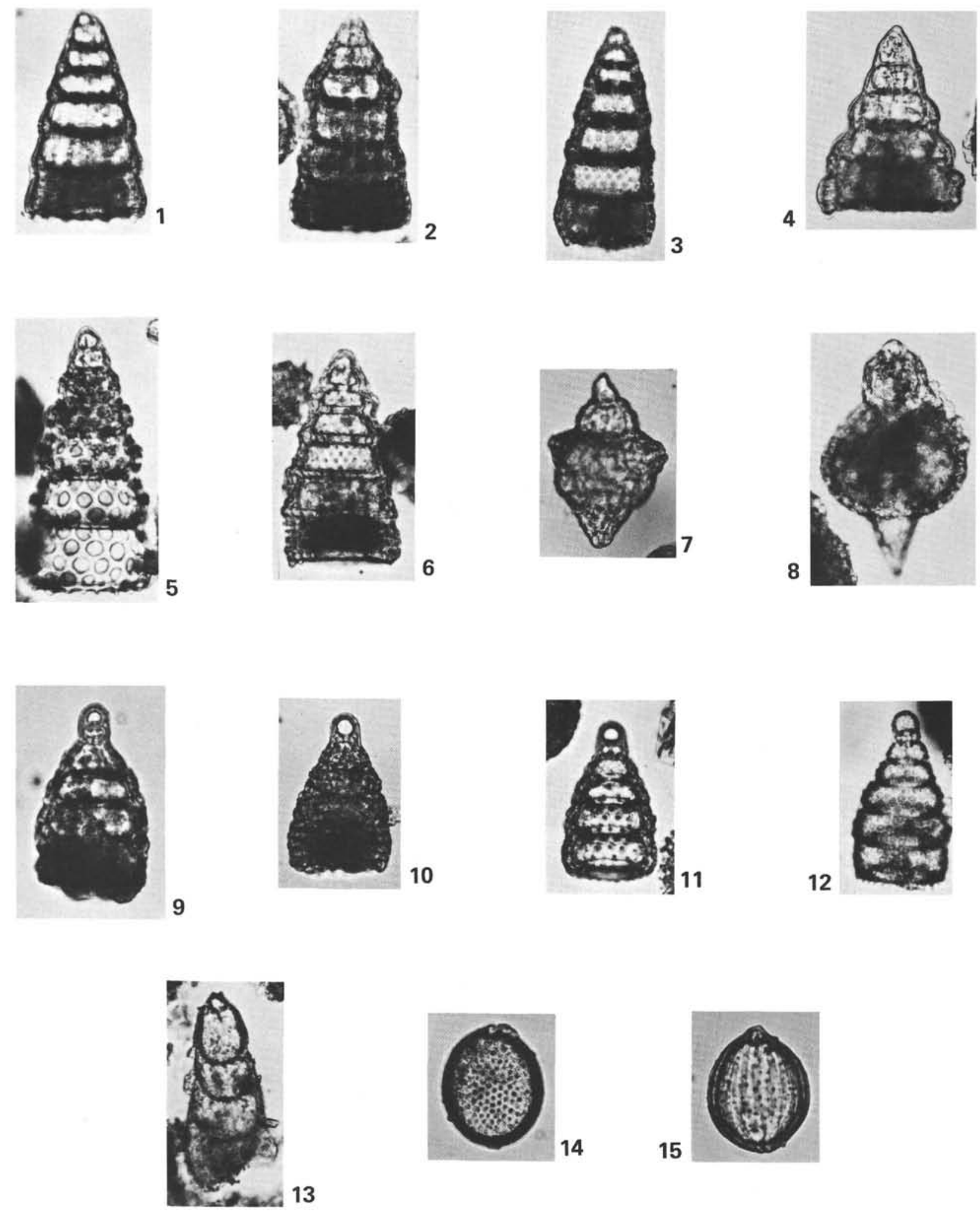


\section{PLATE 9}

Scanning Electron Micrographs of Mesozoic Radiolaria

Figure 1 Stichomitra (?) sp., X400; 49.0-2-CC; Cities Service Oil Company, Exploration/Production Research, Scanning Electron Microscope Negative No. 880.

Figure 2 "Dictyomitra" sp., X400; 52.0-7-CC; CSO, E/P R, SEM Negative Nol 861.

Figure 3 "Dictyomitra" sp., X300; 49.0-2-CC; CSO, E/P R, SEM Negative No. 863.

Figure 4 "Dictyomitra" sp., X550; 59.0-2-CC; CSO, E/P R, SEM Negative No. 882.

Figure 5 Theoperid, gen. et sp. indet., $\times 500 ; 50.0-2-\mathrm{CC}$; CSO, E/P R, SEM Negative No. 871; cf. Pessagno, 1969, Plate 6, Figure 4.

Figure 6 Dictyomitra sp., X275; 46.0-1-CC; CSO, E/P R, SEM Negative No. 886 . 


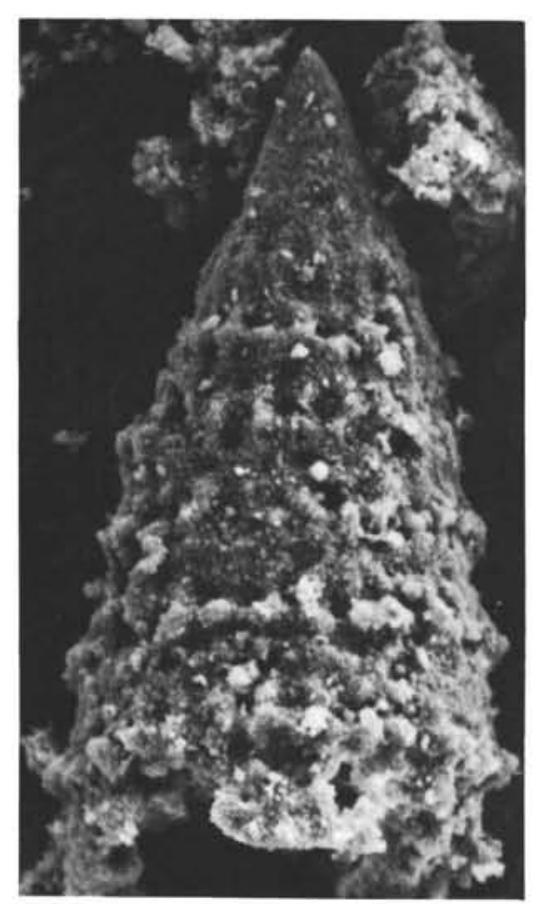

1

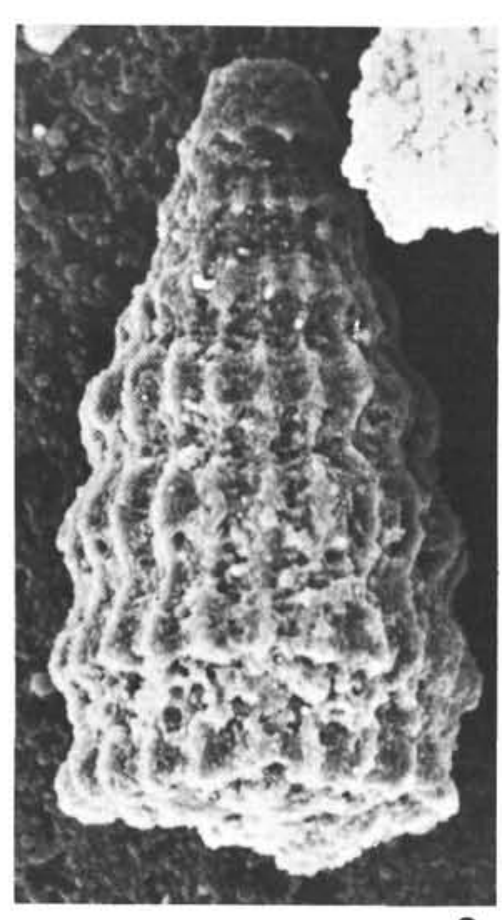

2

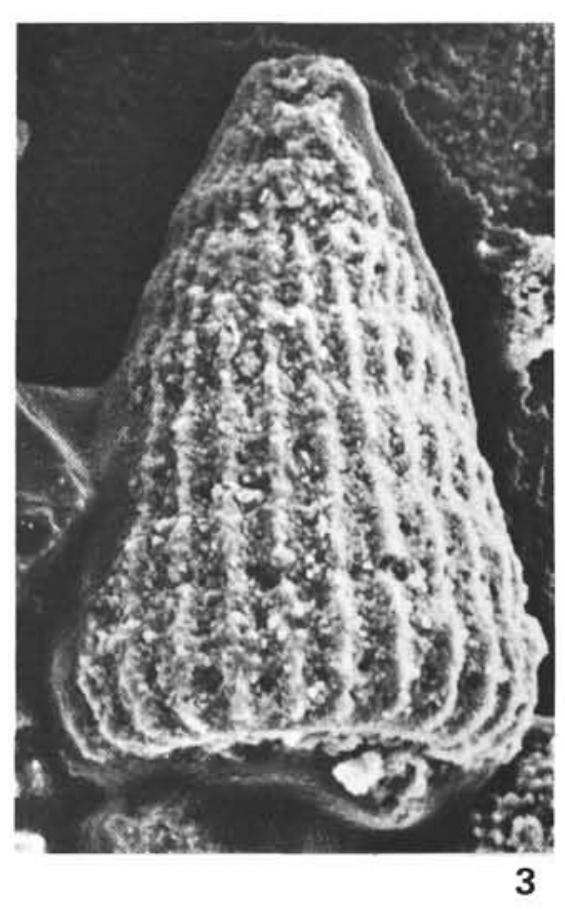

5

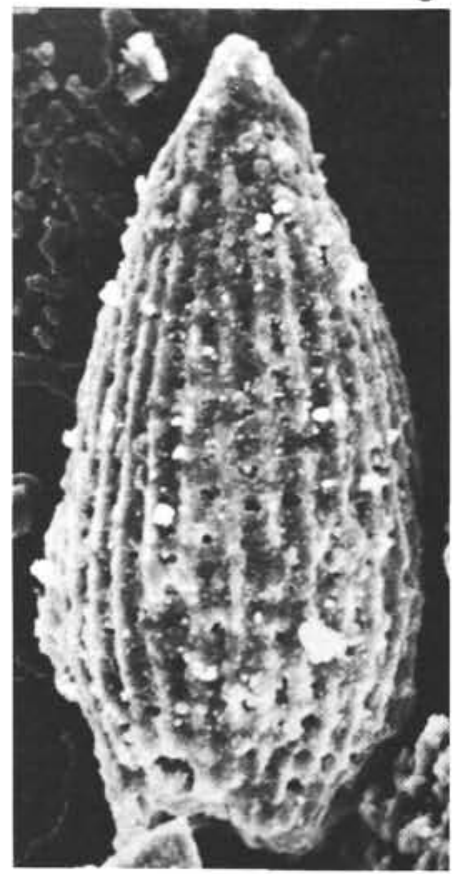

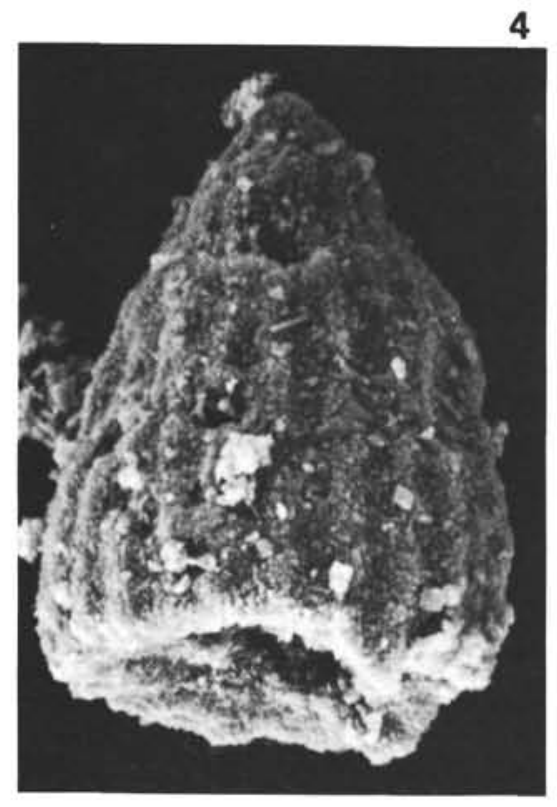




\section{PLATE 10}

Scanning Electron Micrographs of Mesozoic Radiolaria

Figure 1 Theoperid, gen. et sp. indet., X600; 50.0-2-CC; Cities Service Oil Company, Exploration/Production Research, Scanning Electron Microscope Negative No. 864; cf. Pessagno, 1969, Plate 6, Figure 1.

Figure 2 "Dictyomitra" sp., X500; 50.0-2-CC; CSO, E/P R, SEM Negative No. 874.

Figure 3 Stylosphaera sp., X400; 50.0-2-CC; CSO, E/P R, SEM Negative No. 870; cf. Pessagno, 1969, Plate 4 , Figure 4.

Figure $4 \quad$ Dictyomitra sp., X400; 49.0-2-CC; CSO, E/P R, SEM Negative No. 877.

Figure 5 Actinommid, gen. et sp. indet., $\times 275$; 49.0-2-CC; CSO, E/P R, SEM Negative No. 881. 

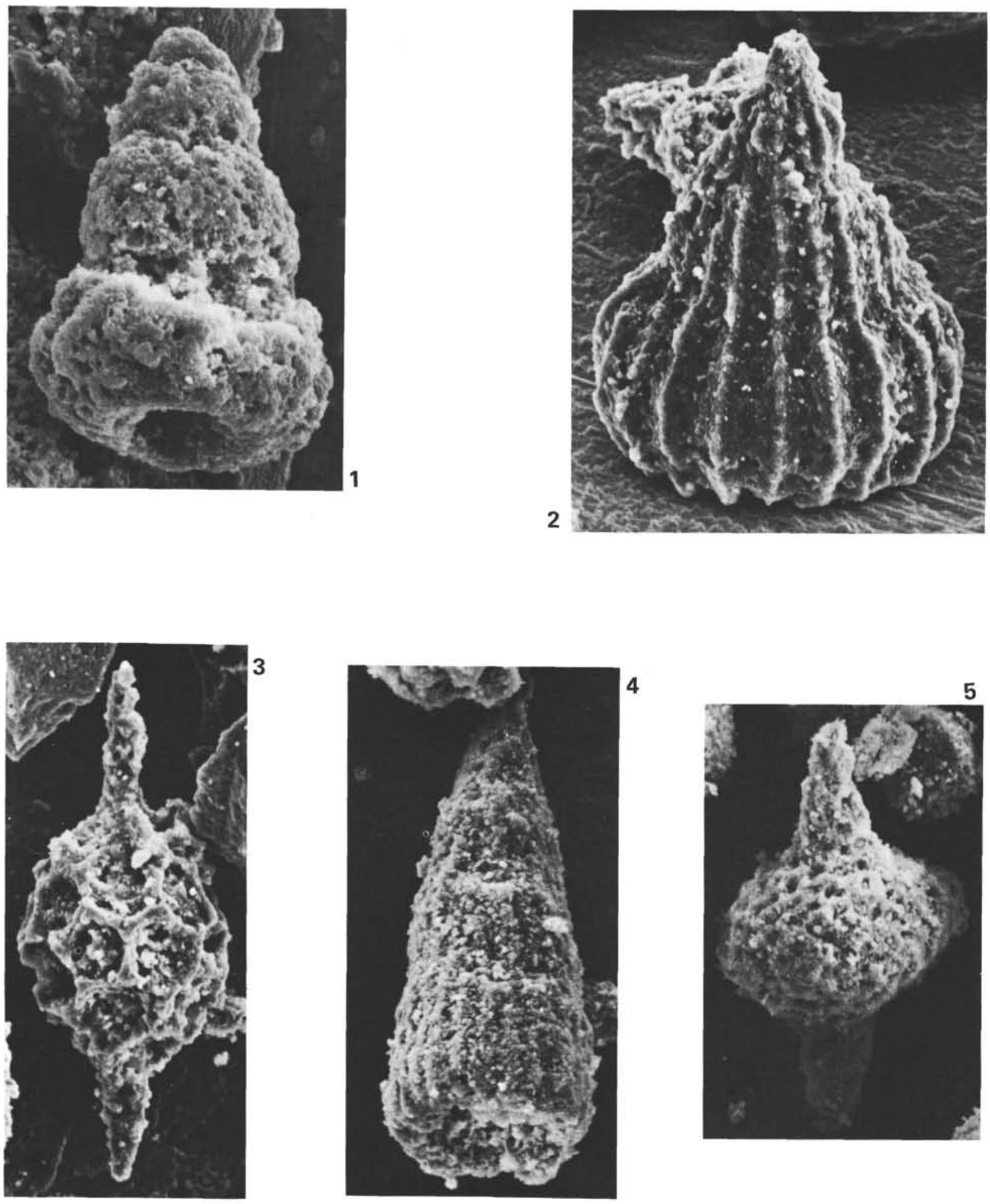


\section{PLATE 11}

Scanning Electron Micrographs of Mesozoic Radiolaria

Figure 1

\section{Figure 2}

Figure 3

Figure 4
Saturnalin gen. et sp. indet., $\times 400$; forms with spine-bearing rings are known only from the Mesozoic; 46.0-1-CC; Cities Service Oil Company, Exploration/Production Research, Scanning Electron Microscope Negative No. 885 .

"Stichocapsa" sp., $\times 275$; positive relief in normal positions of pores suggests this is an integral mold; 46.0-1-CC; CSO, E/P R, SEM Negative No. 888.

Theoperid, gen. et sp. indet., X275; 49.0-2-CC; CSO, E/P R, SEM Negative No. 878.

Theoperid, gen. et sp. indet., X660; 50.0-2-CC; CSO, E/P R, SEM Negative No. 872. 

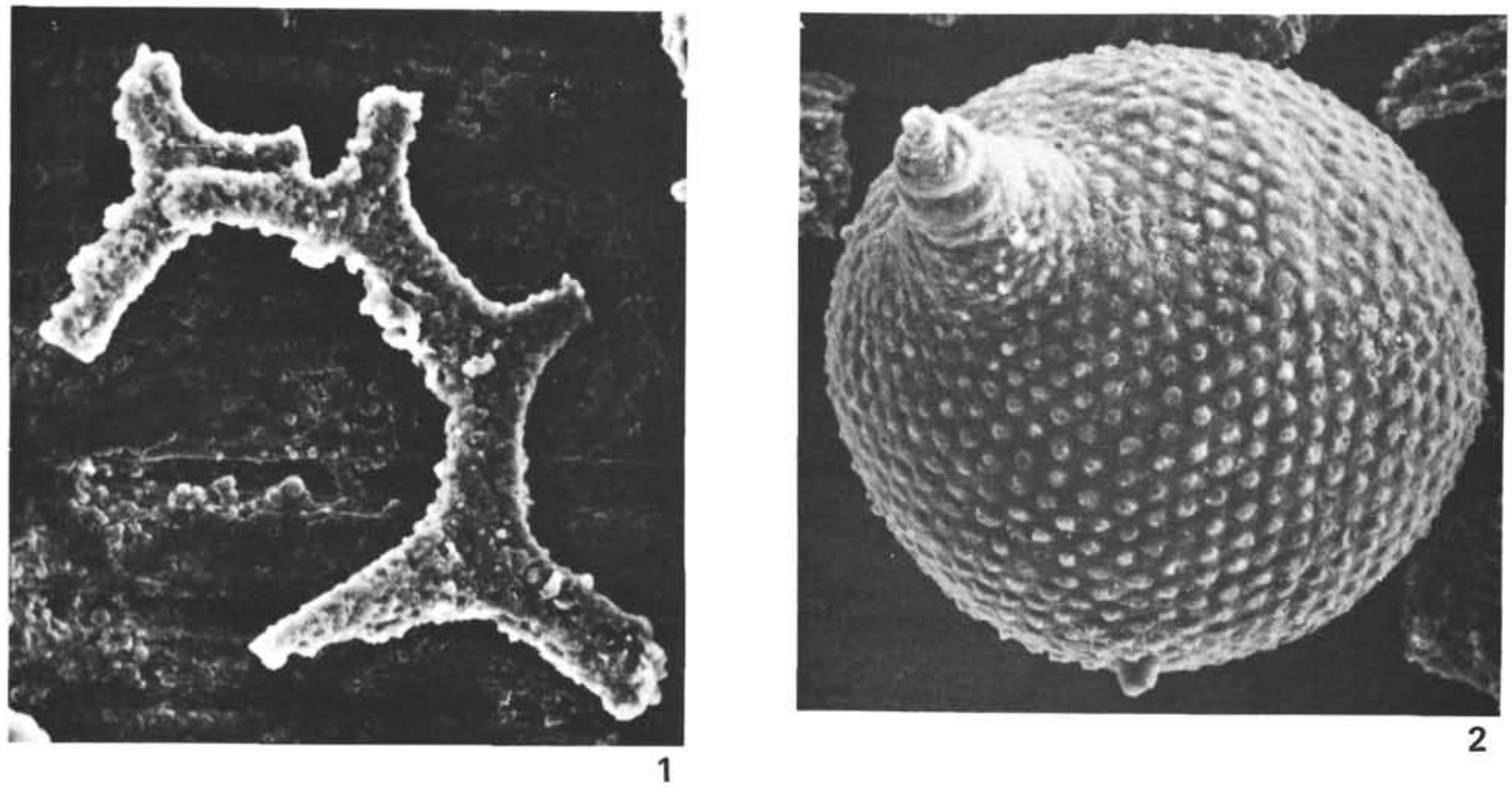

3
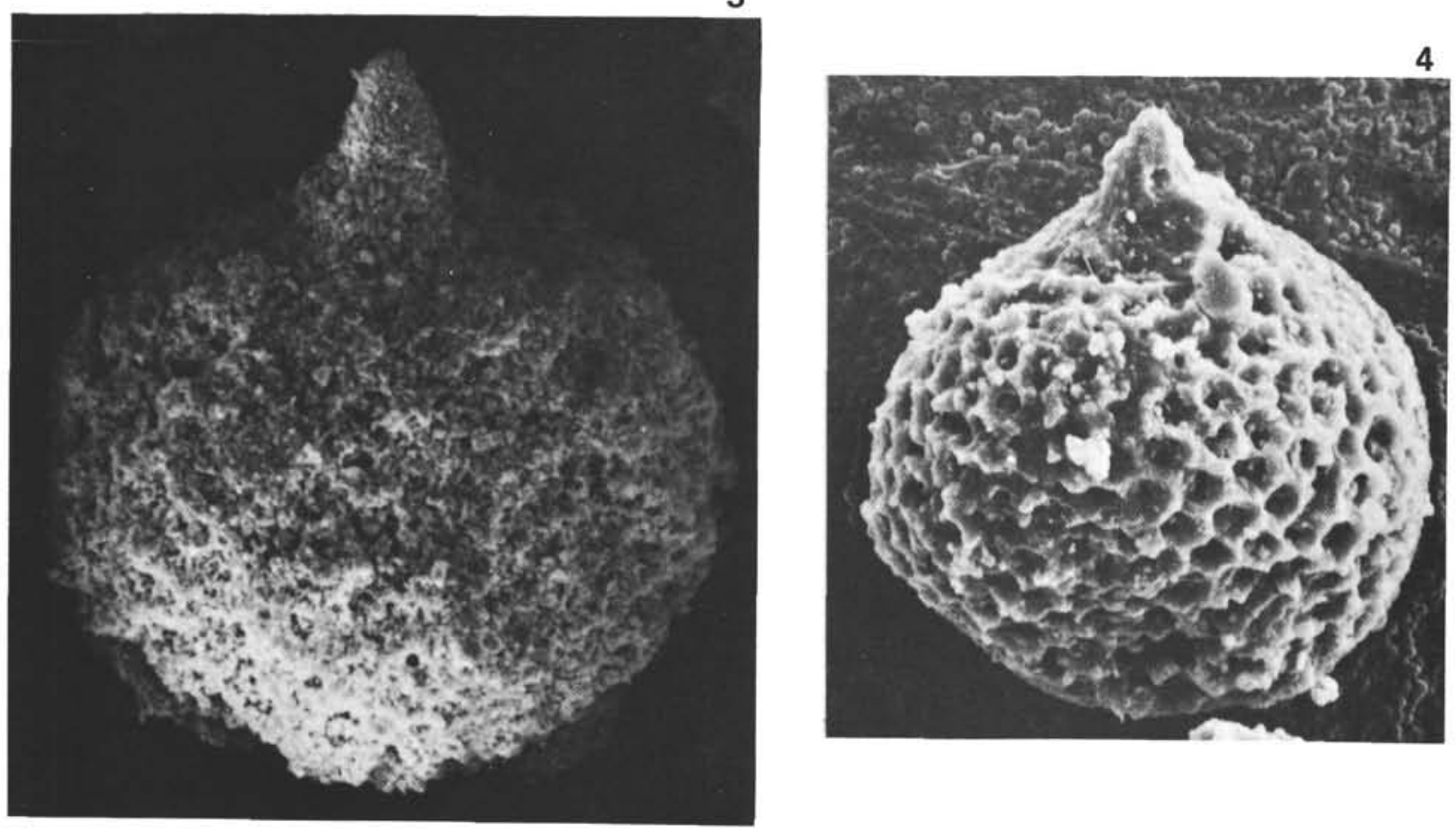